\title{
Pelagic Ostracods of the Genera Halocypris and Felia (Subfamily Halocypridinae) from the North Pacific
}

\section{$\operatorname{AUTHOR}(\mathrm{S})$ :}

CHAVTUR, VLADIMIR G.; STOVBUN, GALINA G.

\section{CITATION:}

CHAVTUR, VLADIMIR G...[et al]. Pelagic Ostracods of the Genera Halocypris and Felia (Subfamily Halocypridinae) from the North Pacific. Publications of the Seto Marine Biological Laboratory 2008, 40(5-6): 55-84

\section{ISSUE DATE:}

2008-04-30

URL:

http://hdl.handle.net/2433/72817

RIGHT: 
Publ. Seto Mar. Biol. Lab., 40 (5/6): 55-84, 2008

\title{
Pelagic Ostracods of the Genera Halocypris and Felia (Subfamily Halocypridinae) from the North Pacific
}

\author{
Vladimir G. Chavtur and Galina G. Stovbun \\ Laboratory of Planktonology, Institute of Marine Biology, Far East Branch, \\ Russian Academy of Science, Vladivostok 690041, Russia \\ vchavtur@imb.dvo.ru
}

\begin{abstract}
Morphology of Halocypris inflata (Dana, 1853), H. pelagica Claus, 1890, Felia cornuta (Müller, 1906) and F. bicornis (Müller, 1906) is examined with North Pacific materials and compared with previous records. Complete synonymy and corrected distribution were given for these species. Halocypris angustifrontalis, new species is described in detail. It differs from known species of this genus by its very large size and the structure of the coxal segment of the mandible. Keys to all species of both genera are presented.
\end{abstract}

Key words: pelagic ostracods, Halocyprididae, Halocypridinae, Halocypris, Felia, North Pacific

\section{Introduction}

Pelagic ostracods of the genera Halocypris (Dana, 1853) and Felia (Poulsen, 1969) inhabit only the tropical and subtropical zones of the World Ocean. Therefore, their finding in other climatic zones clearly suggests the advection of warm waters, e.g., the finding of ostracods of the genus Halocypris in the North Atlantic at $60^{\circ} \mathrm{N}$ (Vavra, 1906), in the Southern Ocean at $49^{\circ} \mathrm{S}$ in the its Pacific sector (Deevey, 1978a) and at $54^{\circ} \mathrm{S}$ in the its Indian sector (Deevey, 1982a), etc. Hence, these species can be useful as bioindicators of water dynamics in the subarctic and subantarctic frontal zones as well as adjacent temperate cold-water areas.

Ostracods of the genus Halocypria predominantly found in the surface layers, although they frequently occur at greater depth, down to 2000-3000 m (Poulsen, 1969a; Deevey, 1978a; 1982a, etc.) and even to $4000 \mathrm{~m}$ (Chen and Lin, 1994b).

The identification of Felia species presents no problems and they are readily distinguishable by shell form. Members of Halocypris are morphologically similar, and up to now is not agreement concerning the number of species.

Despite the fact that Halocypris pelagica was described more than a century ago (Claus, 1890, 1891), merely a few specialists (Brady and Norman, 1896; Brady, 1897; Cleve, 1905; Juday, 1906; Vavra, 1906) recognized its validity at the end of the past and the beginning of the current century. In their classical monographs, Müller (1906a) and Skogsberg (1920) proved that H. pelagica is a junior synonym of $H$. inflata, and all the subsequent zoologists accepted their point of view. Angel (1982) performed the comparative morphological studies of this genus and confirmed the validity of $H$. pelagica. However, other authors continued to merge these species into one - H. inflata. Apparently, the main reason for this treatment appears to be their polymorphism. Nearly all main characters (relative size of the shell, shape of the frontal organ, structure of endopodite of second antenna and the copulatory appendage, etc.) exhibit high variability. Angel (1982) separated these species on the basis of the relative height and thickness of the shell as well as the size of setae "c" and "d" on endopodite of second antenna (in male). However, our studies (unpublished data) suggested that these characters of the specimens from various regions of the Atlantic, Indian and Pacific Oceans showed a very wide range of variability; they often overlap and therefore cannot serve for the differentiation between these species. The intraspecific morphological variation of ostracods of the genus Halocypris within their ranges will be detailed in subsequent works. The present paper describes the morphology of the 
above-noted Halocypris species and also Felia cornuta and F. bicornis from the North Pacific, and compared with the data from previous literature.

In addition to the above-mentioned species of the genus Halocypris, a new species found in collections from the North Pacific is described as Halocypris angustifrontalis, new species.

\author{
Systematics \\ Order HALOCYPRIDA Dana, 1853 \\ Suborder HALOCYPRIDINA Dana, 1853 \\ Superfamily HALOCYPRIDOIDEA Dana, 1853 \\ Family HALOCYPRIDIDAE Dana, 1853 \\ Subfamily HALOCYPRIDINAE Claus, 1891 \\ Genus Halocypris Dana, 1853
}

This genus includes only $H$. inflata (Dana, 1849), $H$. pelagica Claus, 1890 and $H$. angustifrontalis, new species. All these species were found in our samples collected from the North Pacific.

Key to Species of Genus Halocypris

1. Length of male is over $1.7 \mathrm{~mm}$ and female is over $1.8 \mathrm{~mm}$; in female medioventral surface of valves bears row of glands; masticatory surface on coxale of mandible is covered with sensory filaments H. angustifrontalis, new species Length of male is less $1.6 \mathrm{~mm}$ and female is equal or less $1.8 \mathrm{~mm}$; in female medioventral surface of valves is without noticeable glands; masticatory surface on coxale of mandible is covered with spines 2.

2. Shell is small (length of male is $1.00-1.34 \mathrm{~mm}$ and female is $1.00-1.52 \mathrm{~mm}$ ); capitulum of frontal organ is broad (in male mean height is $30 \%$ of its length and in female $26 \%$ ), in female 3 setae are placed on the ventral margin of 1st segment of mandible; copulatory appendage is broad distally H. pelagica Claus, 1890

Shell is large (length of male is $1.30-1.60 \mathrm{~mm}$ and female is $1.48-1.85 \mathrm{~mm}$ ); capitulum of frontal organ is narrow (in male mean height is $24 \%$ of its length and in female $21 \%$ ), in female 2 setae are placed on the ventral margin of 1st segment of mandible; copulatory appendage is narrow distally H. inflata Dana, 1849

\title{
Halocypris angustifrontalis, new species
}

(Figs. 1-5)

? Halocypris brevirostris: Poulsen, 1969a: 65 (part) (stations 4781 and 4788, males 1.6-1.9 mm and females 1.8-2.2 mm), 66 (part), Fig. 25 (for "SE Pacific"), table 8 (for females longer 1.7-1.8 mm from: "Pacific" of $140^{\circ}-33^{\circ} \mathrm{N}, 14^{\circ}-13^{\circ} \mathrm{S}, 33^{\circ}-42^{\circ} \mathrm{S}$ ), table 9 (for males longer $1.6 \mathrm{~mm}$ from: "Pacific" - $33^{\circ}-42^{\circ} \mathrm{S}$, "E Pacific" - $12^{\circ}-22^{\circ} \mathrm{S}$ ); Hanai et al., 1977: 81-82 (part); Hanai et al., 1980: 53-55 (part).

Material examined

Holotype. N1125 - adult male, length $1.82 \mathrm{~mm}$, appendages mounted on slide and valves in alcohol. In collection of the Museum of Institute of Marine Biology, Vladivostok, Russia (together with paratypes).

Type - Locality: R/V SRTM 8-459, station 52, $38^{\circ} 42^{\prime} \mathrm{N}, 129^{\circ} 42^{\prime} \mathrm{W}$, depth 0-100 m, 22 September 1971.

Paratypes. R/V SRTM 8-459: N 1127 - adult male $(1.75 \mathrm{~mm}), \mathrm{N} 1129$ - adult male $(1.63 \mathrm{~mm})$, $\mathrm{N} 1126$ - adult female $(1.80 \mathrm{~mm})$ and $\mathrm{N} 1128$ - adult female $(1.85 \mathrm{~mm})$ from same sample as holotype, 
collected by Plankton Juday's Net $\left(\mathrm{S}=0.1 \mathrm{~m}^{3}\right)$, appendages on slides and valves in alcohol.

\section{Etymology}

The specific name "angustifrontalis", from the Latin "angusta" [=narrow] and "frontalia" [=frontal], refers to size of of capitulum of frontal organ.

Additional material. R/V SRTM 8-459, 1971 - female $(2.00 \mathrm{~mm})$ and male $(1.85 \mathrm{~mm})$, station 46, $38^{\circ} 15 \mathrm{~N}, 125^{\circ} 46 \mathrm{~W}$ layer $0-100 \mathrm{~m}$, September 21 ; female $(1.95 \mathrm{~mm})$, station $48,37^{\circ} 55^{\prime} \mathrm{N}, 127^{\circ} 21^{\prime} \mathrm{W}$, layer 0-100 m, September 21; 5 males (1.70-1.82 mm), station 50, $37^{\circ} 34^{\prime} \mathrm{N}, 128^{\circ} 58^{\prime} \mathrm{W}$, layer $0-100 \mathrm{~m}$, September 22; R/V "Pelamida" 1974 - female (2.12 mm), station 69, sample 50, 33 $30^{\circ} \mathrm{N}, 149^{\circ} 00^{\prime} \mathrm{E}$, layer 25-50 m, June 1; female (2.05 mm), station 69 , sample 50, $33^{\circ} 30^{\prime} \mathrm{N}, 149^{\circ} 00^{\prime} \mathrm{E}$, layer $0-25 \mathrm{~m}$, June 2; female (2.20 mm), same station, sample 51, layer 25-50 m; R/V "Ogon" 1975 - male N1137 $(1.82 \mathrm{~mm})$, male N1138 $(1.77 \mathrm{~mm})$, male N1139 $(1.75 \mathrm{~mm})$, female N1140 (deformed), female N1141 $(2.05 \mathrm{~mm})$ and female $\mathrm{N} 1142(2.07 \mathrm{~mm})$, statin $25,40^{\circ} 10^{\prime} \mathrm{N}, 130^{\circ} 20^{\prime} \mathrm{W}$, layer 0-100 m, September 16; R/V "Seskar" - male N1135 (1.85 mm), station 8, sample 8, 35 30' ${ }^{\circ}, 147^{\circ} 00^{\prime} \mathrm{E}$, laeyr 0-100 m, June 13; female N1136 (2.02 mm), station 29 , sample $29,32^{\circ} 01^{\prime} \mathrm{N}, 143^{\circ} 01^{\prime} \mathrm{E}$, layer 0-100 m, Jule 28; 2 females $(1.80-1.82 \mathrm{~mm})$, station 33 , sample $84,33^{\circ} 29^{\prime} \mathrm{N}, 141^{\circ} 28^{\prime} \mathrm{E}$, layer $0-100 \mathrm{~m}$, July $19 ; 2$ males (1.90 and $1.90 \mathrm{~mm}$ ), station 66 , sample $46,33^{\circ} 30^{\prime} \mathrm{N}, 149^{\circ} 02^{\prime} \mathrm{E}$, layer $0-100 \mathrm{~m}$, July 20 ; female (1.81 $\mathrm{mm}$ ), station 69a, sample 50, $33^{\circ} 14^{\prime} \mathrm{N}, 149^{\circ} 28^{\prime} \mathrm{E}$, layer 0-100 m, July 21; R/V "Pelamida" 1976 - male $\mathrm{N} 1143(1.73 \mathrm{~mm})$, station 11 , sample $12,33^{\circ} 00^{\prime} \mathrm{N}, 149^{\circ} 00^{\prime} \mathrm{E}$, layer $300-400 \mathrm{~m}$, April 26; R/V "Tikhooceansky" 1979 - 3 males (1.65-1.80 mm), 37 $10^{\prime} \mathrm{N}, 127^{\circ} 40^{\prime} \mathrm{W}$, layer 0-100 m, July 14; male $(1.70 \mathrm{~mm})$ and female $(2.00 \mathrm{~mm}), 37^{\circ} 10^{\prime} \mathrm{N}, 124^{\circ} 37^{\prime} \mathrm{W}$, layer $25-50 \mathrm{~m}$, August 15 .

Description of adult male

Shell (Fig. 1, A-D ). The length of the carapace range from 1.63-1.85 mm. Valves are somewhat prolonged, and with equal height at the anterior and posterior parts. Height at the anterior and posterior parts of the valves is equal and 66-71\% (67\% - holotype) the length of their. Dorsal margin is straight, and anterior, ventral and posterior margins are slightly rounded. Rostrum is rudimentary, and rostral incisure is barely noticeable. The asymmetrical gland on the right valve is at the posterior ventral corner and on the left valve opens on a level with the posterior end of the carapace hinge. There is a faint concentric sculpturing.

Frontal organ (Fig. 1, E ). It is narrow, bare, long and extended considerably beyond the down curving distal segments of the 1st antenna. The capitulum is slightly concave medially and down turned distally, and 3 times as long as the stalk. The height of the capitulum is $21-23 \%$ (mean 22\%) the length of it.

First antenna (Fig. 1, E ). The limb is 5-jointed. The dorsal seta on the 2nd segment is inserted vertically and curves anteriorly. It is covered with some short hairs and approximately twice as long as the height of this segment. The setae "a"-"d" are subequal, bare and slightly flatten into a blade distally. The seta "e" is armed with some small hairs, unflattened and 1.5 the length of the setae "a""d" and 3 times as long as the limb (on the dorsal side).

Second antenna (Fig. 1, F-K ). The exopodite is slim and approximately $80 \%$ the length of the protopodite. The total length of the 2 nd-9th segments of the exopodite is about $40 \%$ of the 1 st segment in length. The length of the setae "a"-"d" on the endopodite is very variable (in others specimens and even in one specimen): the seta "c" is longer (holotype), equal or shorter of the seta "a", the seta "d" is longer of the seta "b" (rarely "b" is missing). The seta "e" borne at the 2nd segment is tiny or absent. Shape, size and curve of the cluspers are variable. The clasper on the right limb curves through $90^{\circ}$ at its base and again just over half way along its length. Terminaly it is slightly swollen, or unswollen (holotype), with (holotype)(or without) tiny point and there is subterminal ridging. On the left endopodite the clasper is similar, but weaker and less curved at its base. The largest seta "g" flattens into a blade distally, and is 1.5 the length of the exopodite and 3 times as long as the setae " $h "-$ 


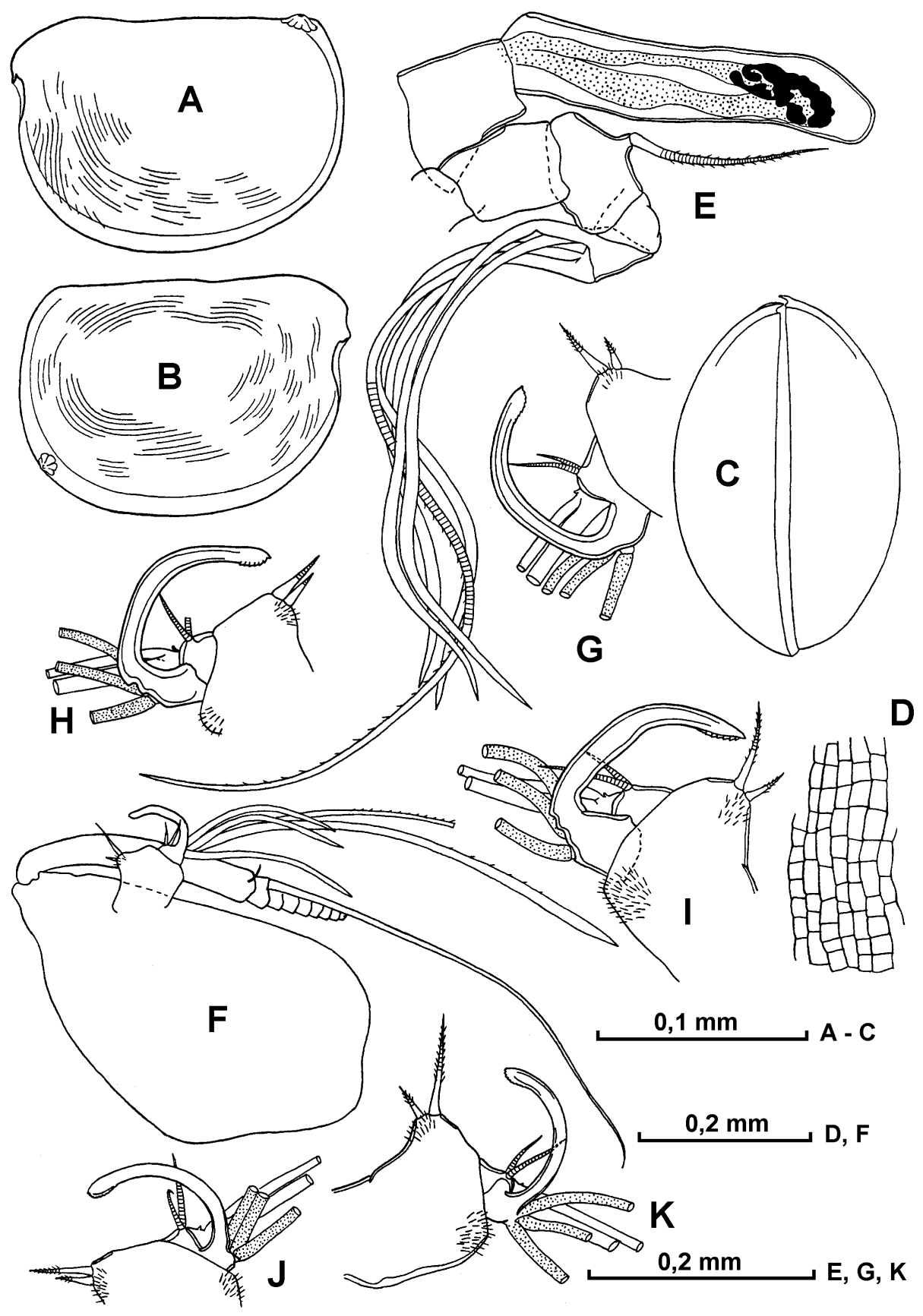

Fig. 1. Halocypris angustifrontalis n. sp. (male: A-D and H - N1129; I and J - N1125; F, G and K- N1127). A and $\mathrm{B}$ - left and right valves of shell in lateral view, C -shell in ventral view, D - sculpturing on shoulder-vault of shell, E - frontal organ and 1st antenna, F - 2nd antenna, G-I - right endopodite of 2nd antenna, J and K - left endopodite of 2 nd antenna. 


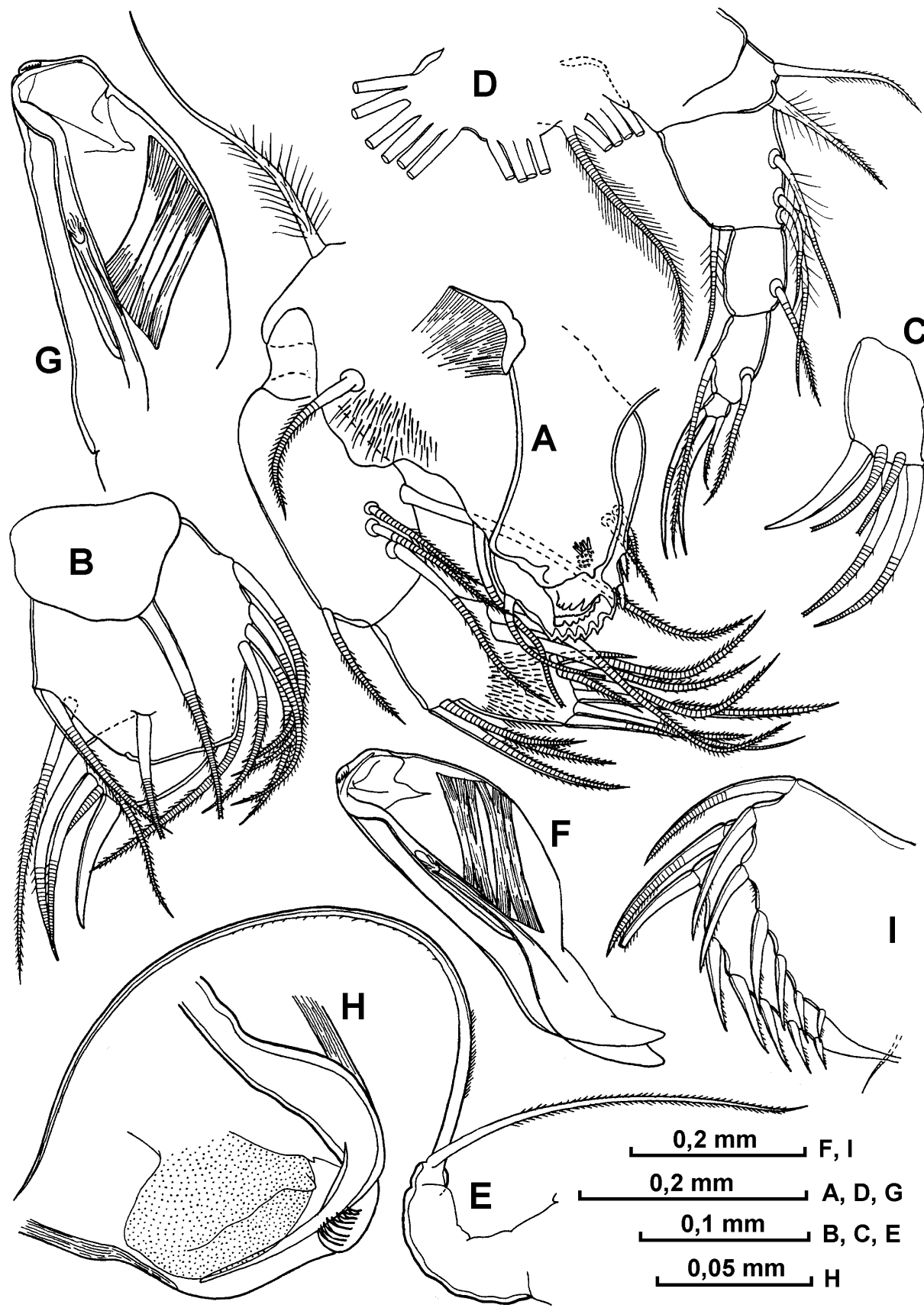

Fig. 2. Halocypris angustifrontalis n. sp. (male: A-D, F, H and I - N1125; E - N1129; G - N1127). A - mandible, B - maxilla, C - terminal segment on endopodite of maxilla, D - 6th limb, E - 7th limb, F and G copulatory appendage , $\mathrm{H}$ - distal part of copulatory appendage, I - caudal furca. 
"j". The seta "f" is unflattened and with some short hairs distally. Surface of the 1st segment is bare or covered with short hairs at the base the seta " $b$ " and near of the its distoventral corner.

Mandible (Figs. 2, A and 5, D, F). The epipodite is developed and without bristle. The exopodite is represented by long stout and plumose seta. The 1st segment of the endopodite bears one short slim dorsal seta, 2 short slim and one long stout lateral and one long stout ventral setae. Last seta is 75 $80 \%$ the length of the endopodite (on dorsal side). On the 2nd segment are placed one long stout and 2 shorter slight dorsal setae, and 2 long stout ventral setae. The 3rd segment is covered with small hairs and armed with 7 terminal setae, of which the 1st dorsal seta and central (main) seta are claw-like, and others are usual. Two ventrolateral setae of this segment bear usual short hairs on the each side. Basale has one stout and one slim anteroventral setae, 2 slim lateral and one stout anterodorsal setae, and anterior dense long hairs near the articulation. Basal endite carries tooth edge with 6 stout terminal and one additional small lateral triangular teeth, and 2 short posterior tube teeth, which are slightly apart. Coxale is armed with ventral tooth edge, and also distal and proximal tooth rows. On the masticatory surface are inserted about 20-30 (about 30 - holotype) sensory filaments (with rounded or pointed tip) and triangular tooth.

Maxilla (Fig. 2, B and C). The basal seta extends noticeable beyond the distal margin of the 1st endopodit segment. The length of this segment is subequal to its height. On the 1st segment are plased 6 anterior, one lateral and 3 posterior setae, and there are no spinules terminally. The 2nd segment is broad and armed with claw and 2 stout setae terminally and with subterminal pair of weaker setae inserted near the base of the central terminal claw.

Fifth limb. The 1st endite of the protopodite has one short seta, and 2nd endite with one long, one short and one minute setae. On the endopodite are placed 3 claw-like and 5 usual setae. The 1 st segment of the exopodite carries one dorsal, 4 lateral and 3 ventral setae (total 8). The dorsal seta of this segment extends slightly beyond the distal margin of the limb. The 2 nd segment bears one dorsal and 2 ventral setae, and 3rd with 2 (dorsal and central) claw-like and one (ventral) usual setae. This limb is without plumose setae.

Sixth limb (Fig. 2, D). The epipodial appendage has 3 groups of 5+4+6 plumose long setae. The endopodite is armed with 2 long setae, of which one is plumose. The 1st segment of the exopodite carries 3 ventral plumose setae and one dorsal plumose seta. Last seta does not reache considerably to the terminal margin of this limb. The 2nd segment bears one ventral seta, the 3rd segment has one dorsal and one ventral setae and is covered with small hairs. On the 4th segment are inserted one short and slim seta (ventrally) and 2 long and stout setae, of which central is claw-like. The dorsal seta does not reache considerably to the distal margin of the limb.

Seventh limb (Fig. 2, E ). It is narrow and long. The largest seta is approximately twice and four times as long as the short seta and the limb, respectively.

Copulatory appendage (Fig. 2, F, G). This appendage is relatively narrow, tapering towards the tip and with greatest height at the medial part. There are 4-6 (6 - holotype) oblique muscle bands, and the tip of the organ has some subterminal spinules.

Caudal furca (Fig. 2, H and I). The furca carries 7 pairs claws and an unpaired dorsal bristle. Inner surface is covered with small hairs.

Description of adult female

Shell (Fig. 3, A-C). The length of the carapace rage from 1.80-2.12 mm. The valves are rounded. The greatest height of the shell is at the posterior part and $74-78 \%$ of its length. The dorsal margin is slightly wavy, and anterior, ventral and posterior margins are rounded. The row glands are placed at the ventromedial part of the valves. Rostrum, rostral incisure, asymmetrical glands and sculpturing are very similar to those of the male.

Frontal organ (Fig. 3, D). The height of the capitulum is 19-22\% (mean 21\%). The rest features are same as in male.

First antenna (Fig. 3, D). Most of the characteristic features of this limb are very similar to those 


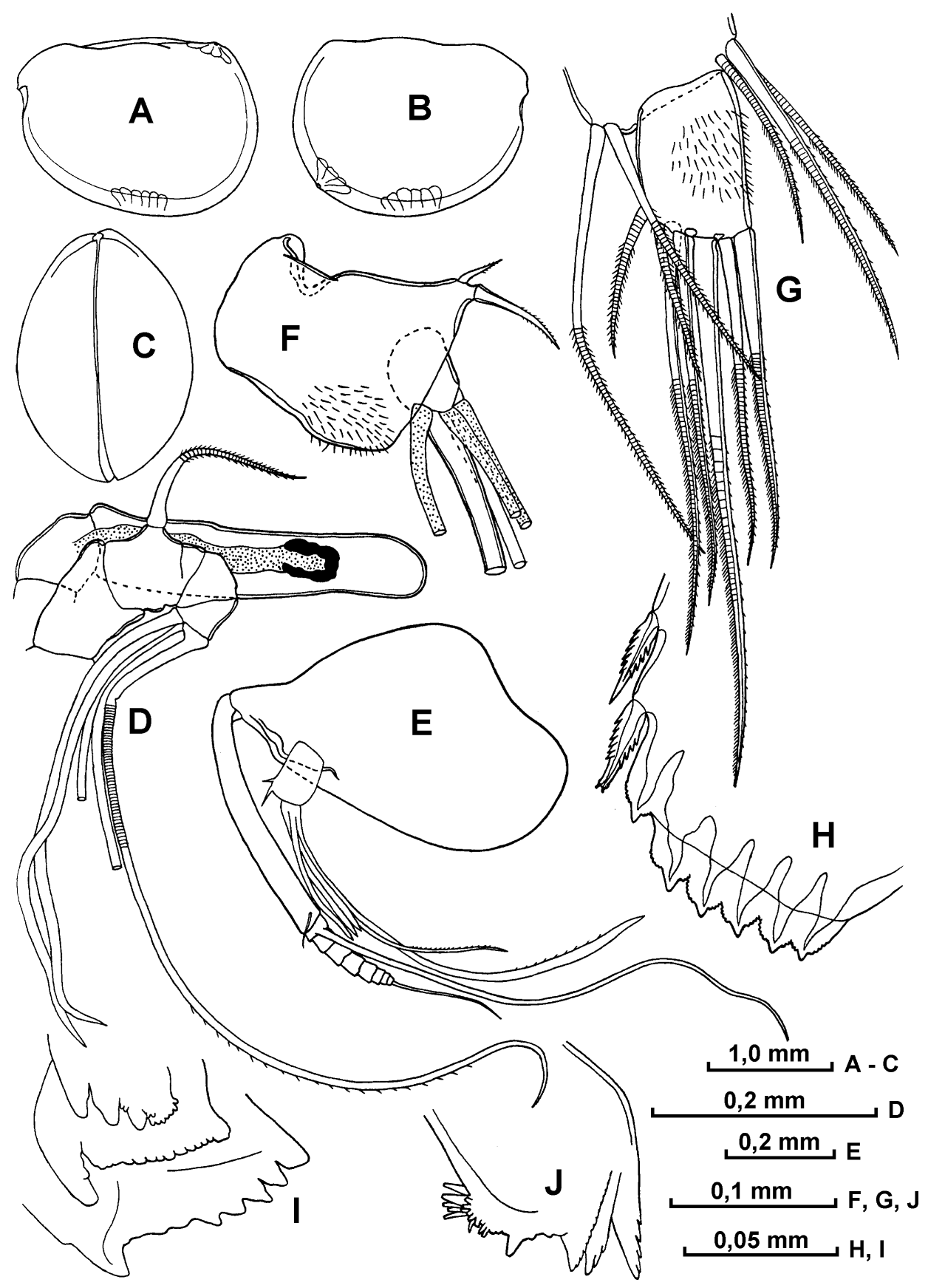

Fig. 3. Halocypris angustifrontalis n. sp. (female: A-C - R/V SRTM 8-459, St. 48; D, G-J - N1126; E and F $\mathrm{N} 1128$ ). A and B - left and right valves of shell in lateral view, C - shell in ventral view, D - frontal organ and 1st antenna, E - 2nd antenna, F - endopodite of 2nd antenna, G - distal part of endopodite of mandible, $\mathrm{H}$ - basal endite of mandible, I and $\mathrm{J}$ - coxal endite of mandible. 
of the male. Only sensory setae "a"-"d" are shorter and about $1 / 2$ the length of the seta "e".

Second antenna (Fig. 3, E and F). The exopodite is slim and subequal to the protopodite. The total length of the 2nd-9th segments of the exopodite is approximately $40 \%$ of the 1 st segment in length.The length of the setae "a" and " $\mathrm{b}$ " on the 1 st segment of the endopodite is very variable. As a rule seta " $\mathrm{b}$ " is twice as long as the seta "a". The largest "g" flattens into a blade distally, and is $1 / 3$ of the exopodite in length and three times as long as the setae " $h "-" j "$. The seta "f" is unflattened and armed few small hairs distally.

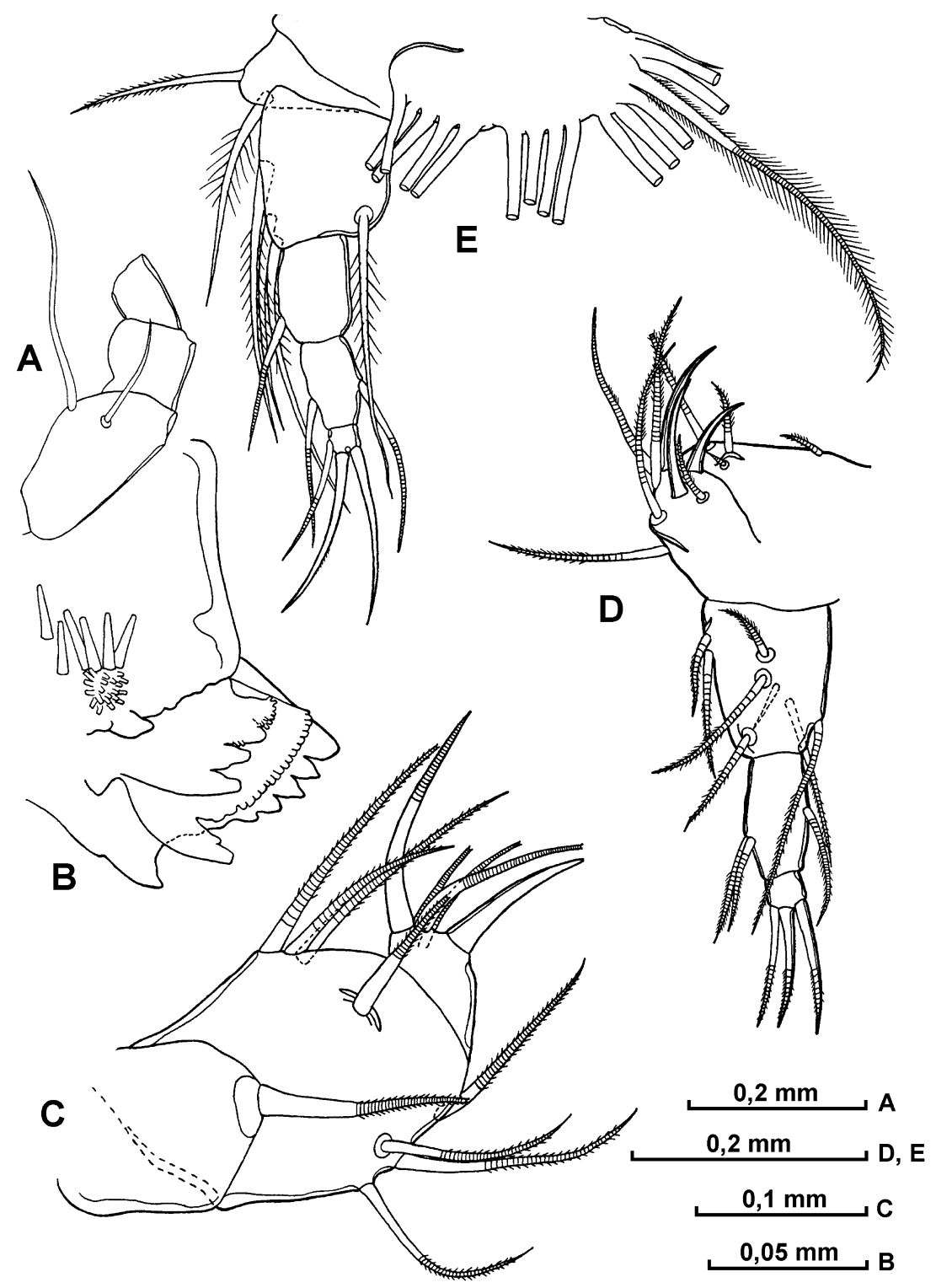

Fig. 4. Halocypris angustifrontalis n. sp. (female - N1126). A - endopodite of mandible, B - coxal endite of mandible, C - maxilla, D - 5th limb, E - 6th limb. 
Mandible (Figs. 3, G-J, 4, A-B and 5, A-C, E). The 1st segment of the endopodite bears one dorsal, one lateral and one ventral setae. Last seta is $65-70 \%$ and largest seta of the 3rd segment is 80 $85 \%$ of the length of the endopodite (on dorsal side), respectively.

Maxilla (Fig. 4, C). The basal seta barely reachs to the distal margin of the 1st segment of the endopodite. This segment is armed with 4 setae.

Fifth limb (Fig. 4, D). It is similar as in male.

Sixth limb (Fig. 4, E). The epipodial appendage has three groups of 5+4+6 long plumose setae and one short bare seta. Two long plumose setae are placed on the endopodite. The dorsal seta inserted on the 1st segment of the exopodite extends beyond the distal margin of the limb.

Seventh limb and caudal furca. As in male.

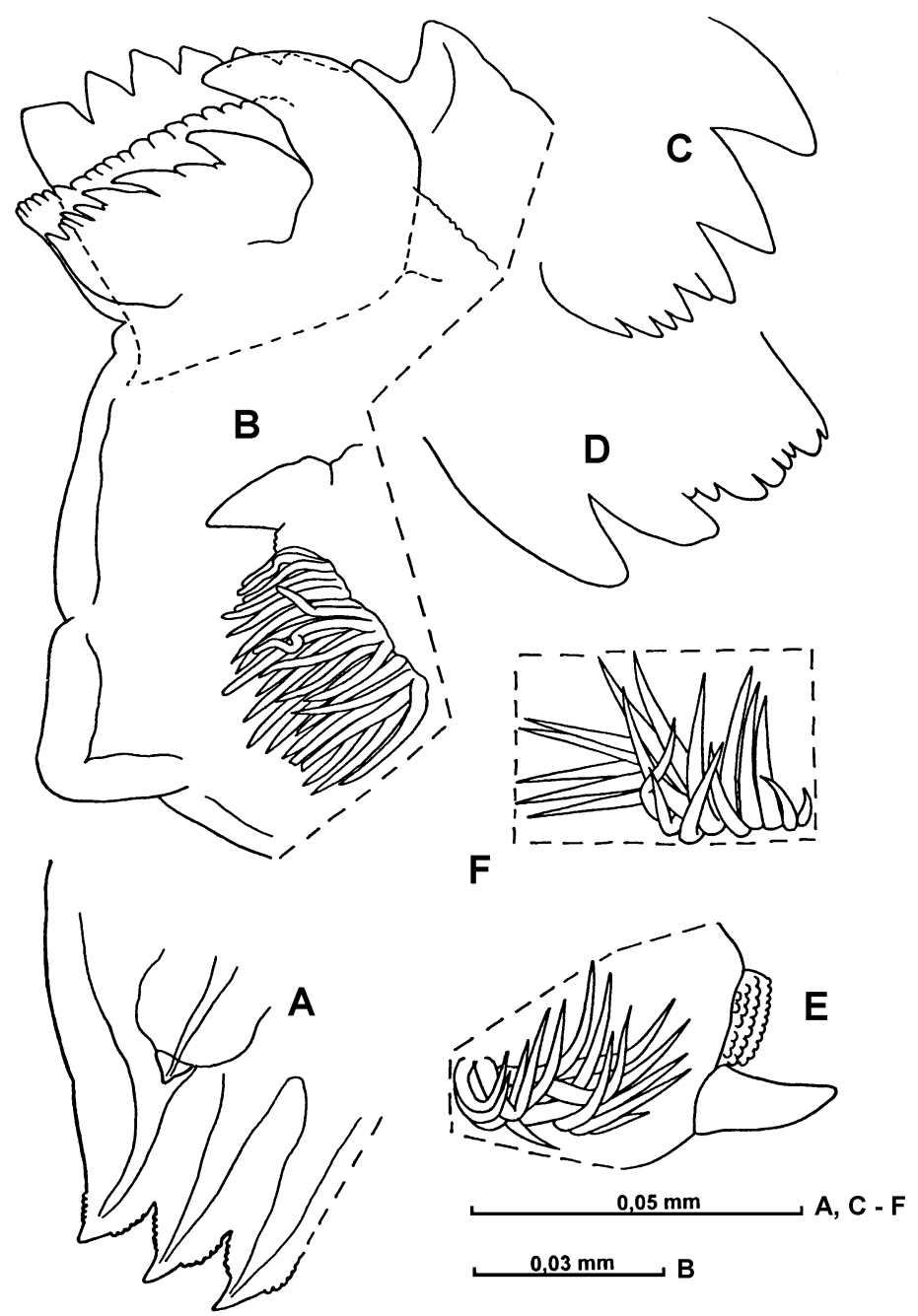

Fig. 5. Halocypris angustifrontalis n. sp. (female: A, B, C - N1142; E - N1136; male D and F - N1135). A ventral part of basal endite on mandible, B- coxale of mandible, $\mathrm{C}$ and $\mathrm{D}$ - proximal tooth row on coxale of mandible, E and F - filaments on masticatory surface of coxale of mandible. 


\section{Comparison}

This species is closely related to $H$. inflata, but differs in having a greatest size of the shell, inserting (in female) of the row from the glands at the ventromedial part of the valves, more narrow capitulum of the frontal organ, and having sensory filaments (instead of spines) on the masticatory surface of the mandible coxale.

This species differs from $H$. pelagica (in addition to the above characters) by less total number of the ventral and lateral setae placed on the 1st segment of the mandible; also less height of the copulatory appendage, and narrower its distal part.

\section{Distribution}

Our specimens of this species were caught in East Pacific between $37-40^{\circ} \mathrm{N}$ and $124-130^{\circ} \mathrm{W}$ in depth range 0-400 $\mathrm{m}$, and in the West Pacific (and Pacific sector of the South Ocean) it was founded in the area $32-35^{\circ} \mathrm{N}$ and $141^{\circ}-149^{\circ} \mathrm{E}$ in laeyr $0-100 \mathrm{~m}$.

Poulsen (1969a) noted finding of the large specimens of $H$. brevirostris for the East Pacific in the latitude range $33^{\circ} \mathrm{N}-42^{\circ} \mathrm{S}$ (? depth). Probably, his specimens belong to H. angustifrontalis new species.

\section{Size}

Studied specimens of males and females of the new species have length range 1.63-1.95 mm and 1.80-2.20 mm, respectively. Poulsen's (1969a) specimens of males have maximum length $1.88 \mathrm{~mm}$, and length of females $1.88-2.15 \mathrm{~mm}$.

\section{Halocypris pelagica Claus, 1890}

(Figs. 6-10)

Halocypris pelagica Claus, 1890: 25; 1891: 78, Pl. 21, Figs. 1-11; Brady and Norman, 1896: 703704; Brady,1897: 97; Cleve, 1905: 131; Juday, 1906: 27-28, pl. 7, figs. 4-7; Vavra, 1906: 64-65; Angel,1982: 329-335, figs, 2, 3, 5-8, 10, 13,14, tables 1-3.

? Halocypris distincta Claus, 1890: 25.

Halocypris brevirostris: Skogsberg, 1920: 585 (only male in length $0.95 \mathrm{~mm}$ : station 116, $15^{\circ}$ 46 'S-34 ${ }^{\circ}$ 'W); Deevey, 1968: 19-20, Figs. 2a-f, 3c-e; 1974: 358-359 (part); Angel, 1968: 305; 1969a: 540, tables 2, 3; 1969b: 78; 1979: 74-77, Figs. 67, 68 (only exceptions neuston specimens at $30^{\circ} \mathrm{N}$ $23^{\circ} \mathrm{W}$ ); Poulsen, 1969a: 66 (part), Fig. 25 (for females shorter $1.4 \mathrm{~mm}$ from "W. Pacific"), table 8 (for female shorter $1.4 \mathrm{~mm}$ from: "Atlantic" - $26^{\circ}-33^{\circ} \mathrm{N}$, "E. Pacific" - $11^{\circ}-23^{\circ} \mathrm{S}$ ), table 9 (for male shorter $1.3 \mathrm{~mm}$ from: "Atlantic" - $27^{\circ}-31^{\circ} \mathrm{N}$, "E. Pacific" - $12^{\circ}-22^{\circ} \mathrm{S}$, "Atlantic-Indian" - $4^{\circ} \mathrm{N}-28^{\circ} \mathrm{S}$, "Pacific" $-11^{\circ} \mathrm{N}-13^{\circ} \mathrm{S}, 33^{\circ}-42^{\circ} \mathrm{S}$ ); Ramires and Moguilevsky, 1971: 640; Chavtur, 1976: 104; 1977a: 30 (part); 1977b: 20 (part); Hanai et al., 1977: 81-82 (part); Hanai et al., 1980: 53-55 (part); Tseng, 1980: 415416 (part: only male in length $1.1 \mathrm{~mm}$ ) and Chen and Lin, 1995: 53.

Halocypris inflata: Müller, 1906a: 50-51 (part); 1912: 58-59 (part); Chen et al., 1983: 87-88, Fig. 5; Chavtur, 1992: table 2 (part).

? Halocypris brevirostris: Chen, 1980: 64, figs. 10-13; 1984: 89; Chen and Lin, 1991: 294; 1994a : 403, 404, 406, 408; 1994b: 414, 415, 416, 417, 419, 420, table 2; 1994c: 447, 448, 449, 450.

? Halocypris inflata: Chen, 1978: 41; Chen, 1982: 290, 291, 293, 296; Yin et al., 1991: 86.

Material examined

R/V "Orlyk" 1967 - male N1181 (1.25 mm), 26 00'N, 138 12'E, layer 0-100 m, May 19; male $\mathrm{N} 1182(1.15 \mathrm{~mm})$, male N1183 $(1.23 \mathrm{~mm})$, male N1184 $(1.15 \mathrm{~mm})$, female N1185 (deformed), female $\mathrm{N} 1186(1.25 \mathrm{~mm}) 31^{\circ} 30^{\prime} \mathrm{N}, 149^{\circ} 00^{\prime} \mathrm{E}$, layer $0-100 \mathrm{~m}$, male N1187 $(1.12 \mathrm{~mm}), 31^{\circ} 30^{\prime} \mathrm{N}, 142^{\circ} 21^{\prime} \mathrm{E}$, layer $0-100 \mathrm{~m}$, June 3 .

Additional material: R/V SRT 662,1953 - female $(1.2 \mathrm{~mm})$, station $21,35^{\circ} 14^{\prime} \mathrm{N}, 152^{\circ} 07^{\prime} \mathrm{E}$, layer 0 - 


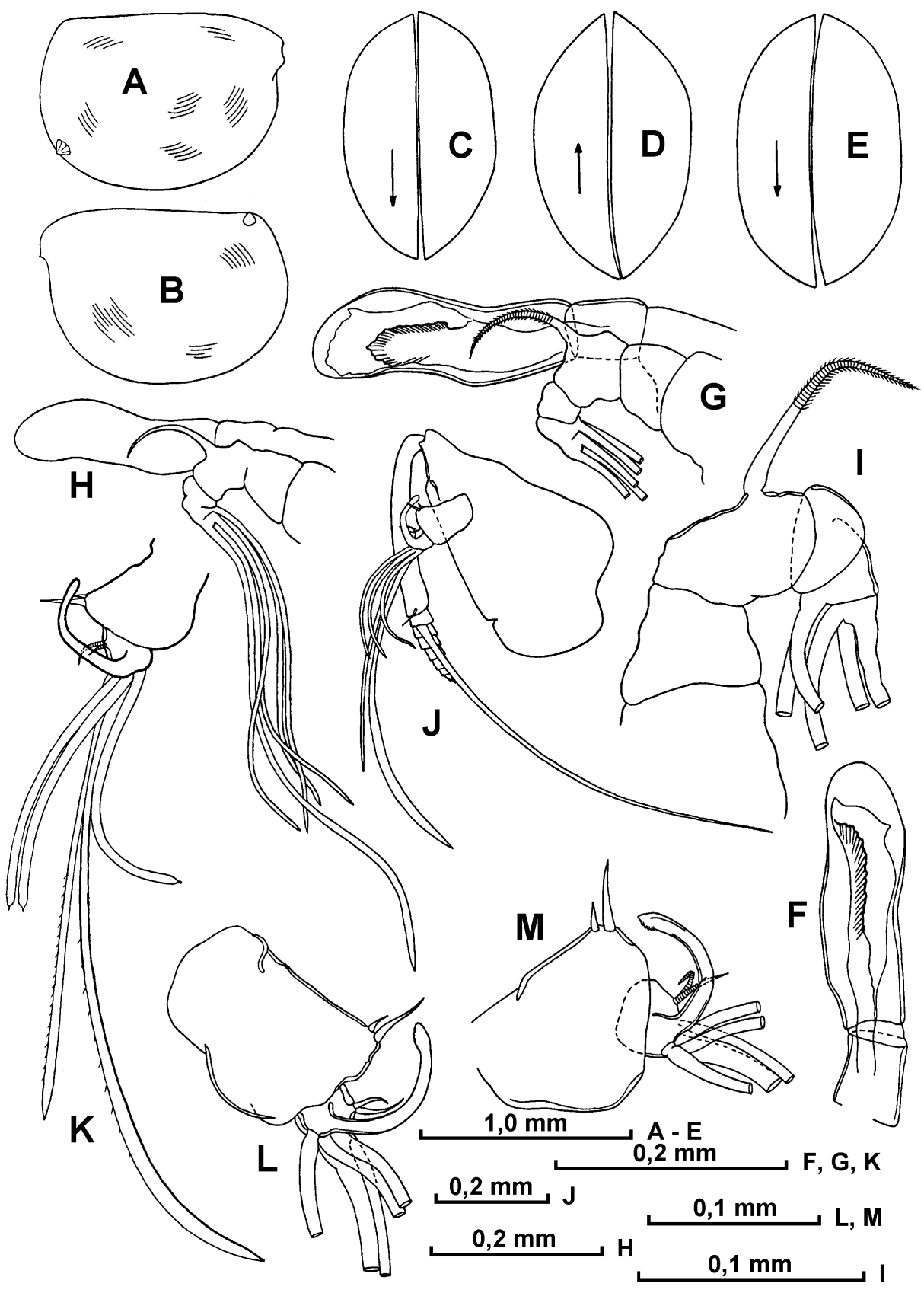

Fig. 6. Halocypris pelagica (male: A-C and F-1182; D, J-L - N1184; E and M - N1183; G and H - N1185). A and B - right and left valves of shell in lateral view, C-E - shell in ventral view, F - frontal organ, $\mathrm{G}$ and $\mathrm{H}$ - frontal organ and 1st antenna, I - 1st antenna, J - 2nd antenna, K - right endopodite of 2nd antenna, L and $\mathrm{M}$ - left endopodite of 2 nd antenna. 


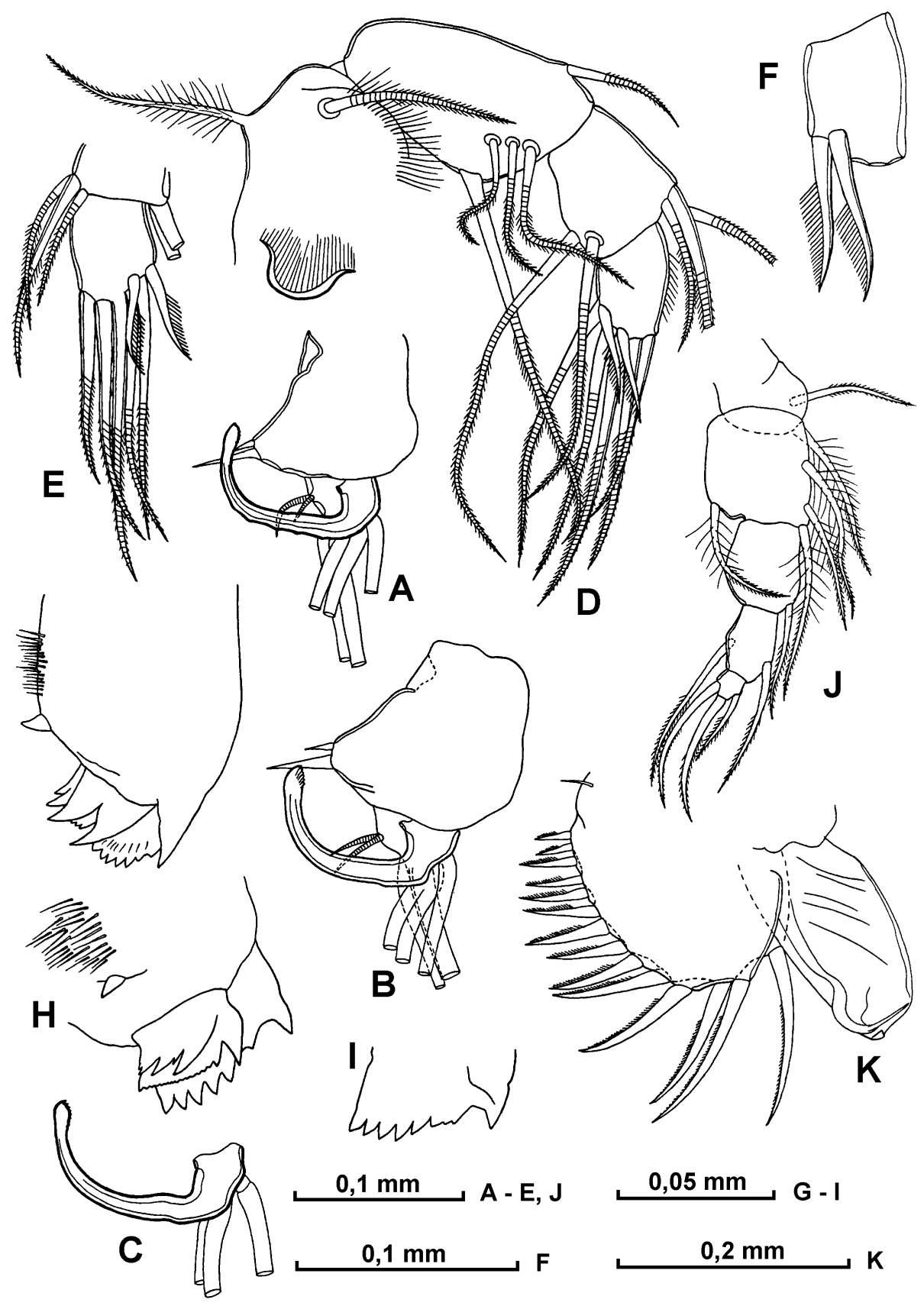

Fig. 7. Halocypris pelagica (male: A, E and J - N1182; B, D, G-I - N1183; C, F and K - N1184). A and B - right endopodite on 2nd antenna, C - right clasper of endopodite on 2nd antenna, D - mandible, E and F - distal part of mandible of endopodite, $\mathrm{G}$ and $\mathrm{H}$ - endite and masticatory pad on coxale of mandible, I - tooth edge on coxale of mandible, $\mathrm{J}$ - 6th limb, $\mathrm{K}$ - copulatory appendage and caudal furca. 


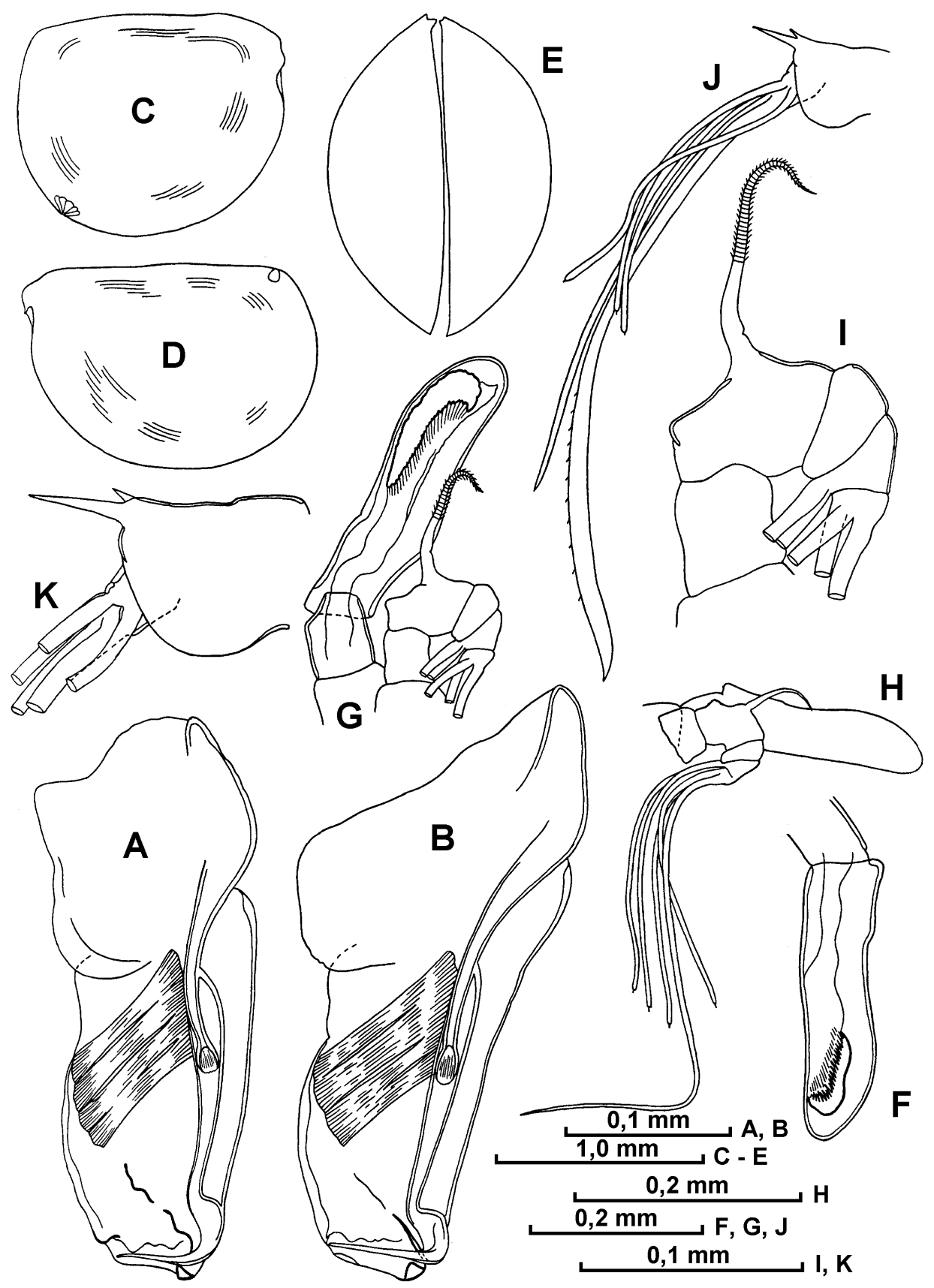

Fig. 8. Halocypris pelagica (male: A - without and B under covered glass -N1182, female: C, G, I and J - N1185; D-F, H and K - N1186). A and B - copulatory appendage, C and D - right and left valves of shell with lateral view, $\mathrm{E}$ - shell with ventral view, F - frontal organ, G and $\mathrm{H}$ - frontal organ and 1st antenna, I - 1st antenna, $\mathrm{J}$ and $\mathrm{K}$ - endopodite of $2 \mathrm{nd}$ antenna. 
$200 \mathrm{~m}$, July 16; R/V "Vityaz" 20th cruise, 1955 - 2 males (1.14-1.20 mm), 2 females (1.30-1.38 mm) and 5 juveniles $(0.65-0.80 \mathrm{~mm})$, station $3228,37^{\circ} 18^{\prime} \mathrm{N}, 145^{\circ} 16^{\prime} \mathrm{E}$, layer $200-500 \mathrm{~m}$, May 3; R/V "Vityaz" 29th cruise, 1958 - female (1.25 mm), station 4197, 35 $06^{\circ} 3 \mathrm{~N}, 139^{\circ} 58^{\prime} 5 \mathrm{~W}$, layer $0-200 \mathrm{~m}$, December 11; R/V "Orlyk" 1967 - juvenile $(0.70 \mathrm{~mm}), 37^{\circ} \mathrm{N}, 149^{\circ} \mathrm{E}$, layer 0-100 m, April 30; male $(1.17 \mathrm{~mm}), 4$ females $(1.35-1.39 \mathrm{~mm})$ and 2 juveniles $(0.95-0.98 \mathrm{~mm}), 35^{\circ} 26^{\prime} \mathrm{N}, 143^{\circ} 53^{\prime} \mathrm{E}$, layer $0-100$ $\mathrm{m}$, May 5; juvenile $(0.70 \mathrm{~mm}), 33^{\circ} 40^{\prime} \mathrm{N}, 139^{\circ} 12^{\prime} \mathrm{E}$, layer $0-100 \mathrm{~m}$, May $14 ; 4$ males $(1.20-1.25 \mathrm{~mm}), 3$ females $(1.32-1.35 \mathrm{~mm})$ and 4 juveniles $(0.72-0.80 \mathrm{~mm}), 31^{\circ} 29^{\prime} \mathrm{N}, 138^{\circ} 14^{\prime} \mathrm{E}$, layer $0-100 \mathrm{~m}$, May 16 ; male $(1.30 \mathrm{~mm}), 31^{\circ} 55^{\prime} \mathrm{N}, 138^{\circ} 11^{\prime} \mathrm{E}$, layer $0-100 \mathrm{~m}$, May 16 ; juvenile $(1.0 \mathrm{~mm}), 30^{\circ} 30^{\prime} \mathrm{N}, 138^{\circ} 12^{\prime} \mathrm{E}$,

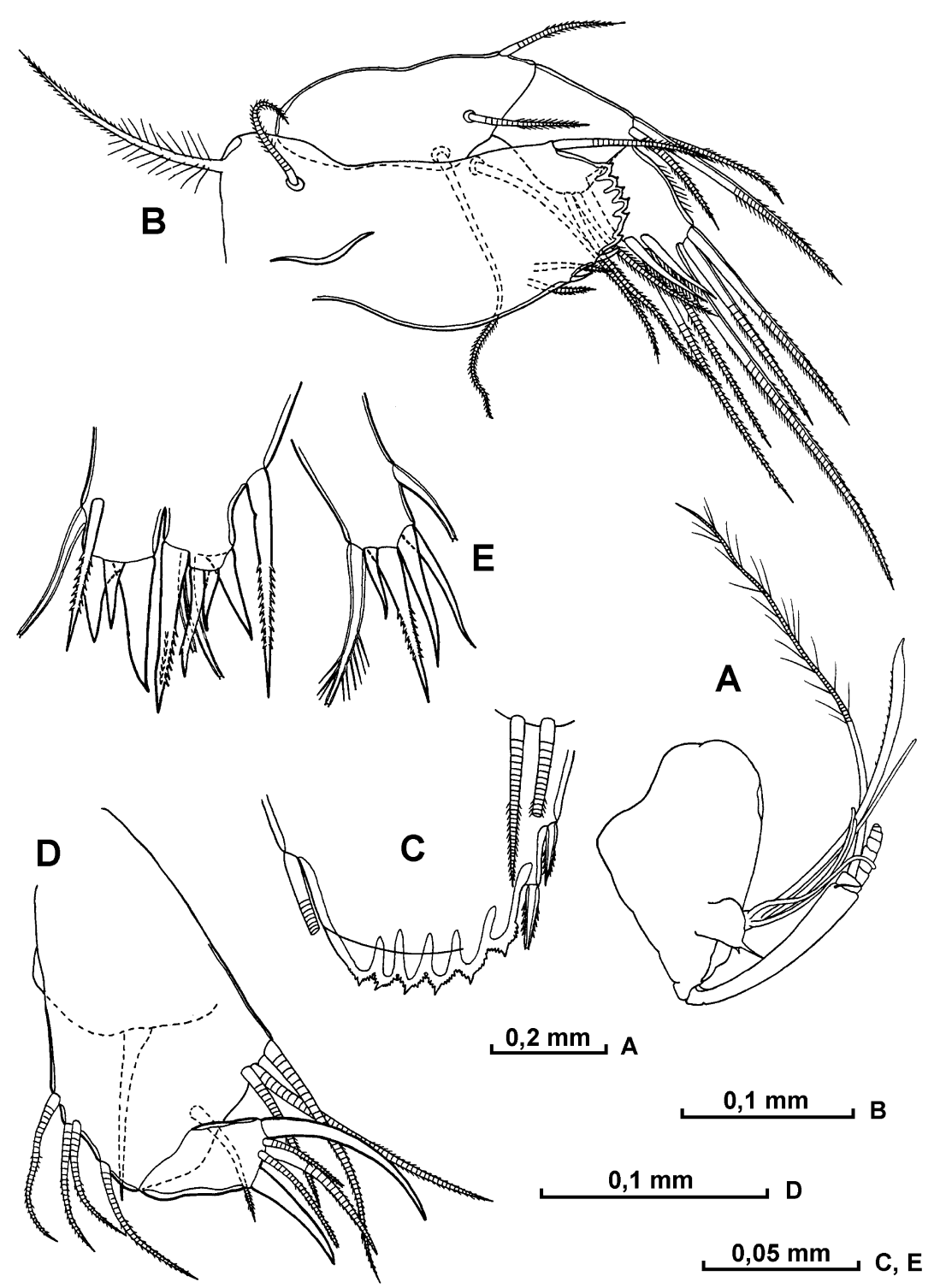

Fig. 9. Halocypris pelagica (female: A, C and E - N1185; D - N1186). A - 2nd antenna, B - mandible, C - basal endite of mandible, D - endopodite and basale of mandible, E - coxal and precoxal endites of maxilla. 
layer 0-100 m, May 17 ; female $(1.29 \mathrm{~mm})$ and 2 juveniles $(0.85-0.90 \mathrm{~mm}), 27^{\circ} 00^{\prime} \mathrm{N}, 138^{\circ} 12^{\prime} \mathrm{E}$, layer $0-100 \mathrm{~m}$, May $19 ; 2$ juvenile $(0.80-0.87 \mathrm{~mm}), 26^{\circ} 00^{\prime} \mathrm{N}, 138^{\circ} 12^{\prime} \mathrm{E}$, layer $0-100 \mathrm{~m}$, May 19 ; juvenile $(0.95 \mathrm{~mm}), 21^{\circ} 54^{\prime} \mathrm{N}, 138^{\circ} 18^{\prime} \mathrm{E}$, layer $0-100 \mathrm{~m}$, May 21 ; female $(1.43 \mathrm{~mm})$ and 4 juveniles $(0.70-1.00$ $\mathrm{mm}), 21^{\circ} \mathrm{N}, 149^{\circ} \mathrm{E}$, layer 0-100 m, May 21; 2 males (1.15-1.25 mm) and 7 juveniles (0.63-1.00 mm), $31^{\circ} 30^{\prime} \mathrm{N}, 149^{\circ} 00^{\prime} \mathrm{E}$, layer $0-100 \mathrm{~m}$, May 29 ; male $(1.20 \mathrm{~mm}), 33^{\circ} 42^{\prime} \mathrm{N}, 147^{\circ} 32^{\prime} \mathrm{E}$, layer 0-100 $\mathrm{m}$, May 31; R/V "Orlyk" 1969 - juveniles (0.73-0.80 mm), station 10(54), sample 22, $40^{\circ} \mathrm{N}, 149^{\circ} \mathrm{E}$, level 300 m, Junuary 29; R/V "Izumrud" 1969 - juvenile (1.07 mm), station 45, sample 46, approximately $42^{\circ}$ $30^{\prime} \mathrm{N}, 135^{\circ} 00^{\prime} \mathrm{E}$, layer 0-100 m, June 24; R/V "Iskatel" 1969 - juvenile $(0.70 \mathrm{~mm})$, station 136, sample

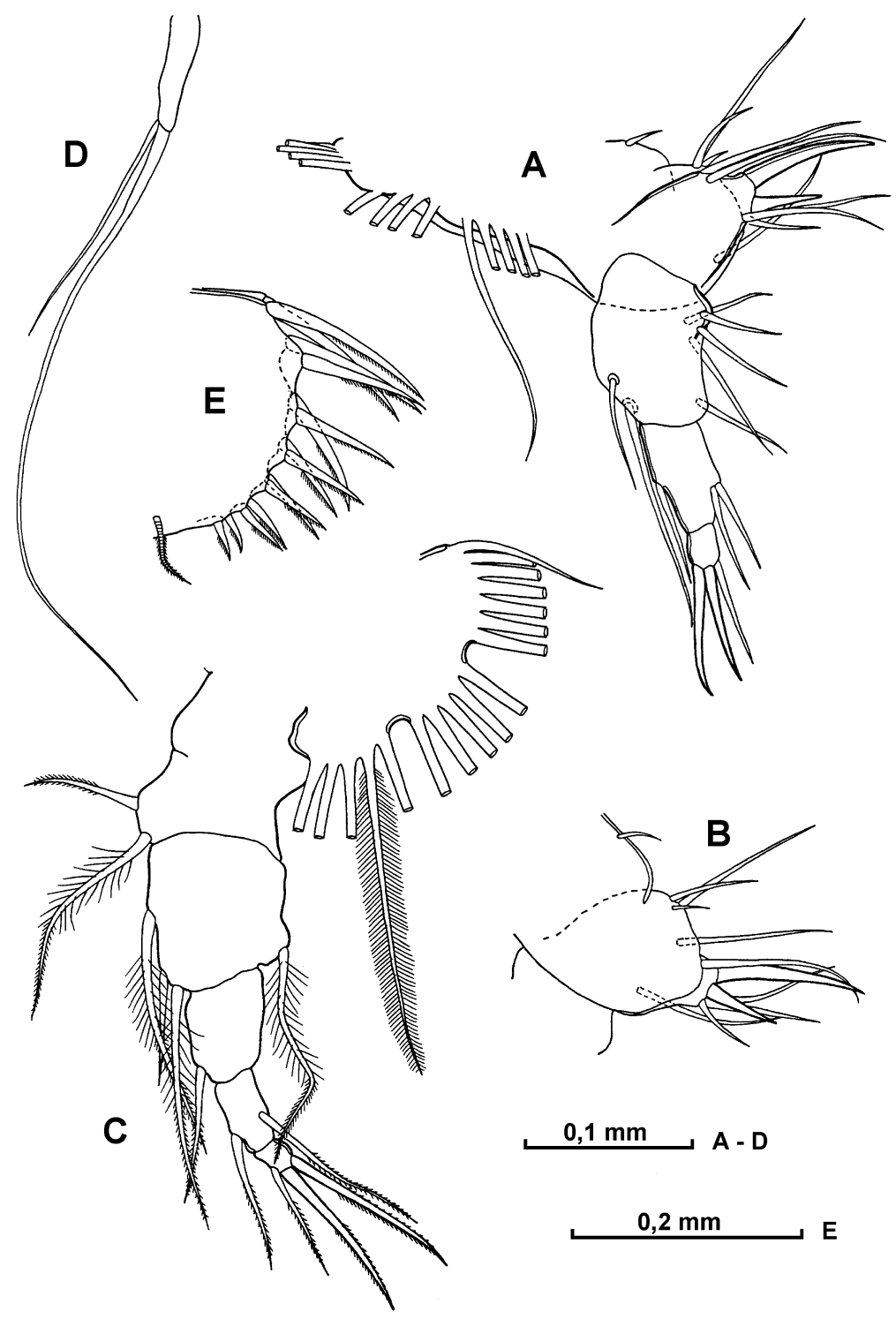

Fig. 10. Halocypris pelagica (female: A-C and E - N1186; D- N1185). A - maxilla, B - endopodite of maxilla, C 6th limb, D - 7th limb, E - caudal furca. 
90, $36^{\circ} 07^{\prime} 6 \mathrm{~N}, 142^{\circ} 45^{\prime} 0 \mathrm{E}$, layer 0-100 m, September 6; R/V "Ucheny" 1970 - juvenile (0.85 mm), station 94 , sample $113,35^{\circ} 57^{\prime} \mathrm{N}, 138^{\circ} 09^{\prime} \mathrm{E}$, layer 0-100 m, November 18; R/V "Orlyk" 1971 - female (deformed), station?, sample 60, $37^{\circ} 30^{\prime} \mathrm{N} 149^{\circ} 00^{\prime} \mathrm{E}$, layer 0-100 m, August 3; R/V "Shantar" 1977 juvenile $(0.97 \mathrm{~mm})$, station $78,33^{\circ} 32^{\prime} \mathrm{N}, 127^{\circ} 15^{\prime} \mathrm{W}$, layer 0-200 m, April 19; R/V "Cavalerovo" 1980 - juvenile $(0.70 \mathrm{~mm})$, station $30,39^{\circ} 00^{\prime} \mathrm{N}, 149^{\circ} 00^{\prime} \mathrm{E}$, layer $0-100 \mathrm{~m}$, August 23 ; juvenile $(0.75 \mathrm{~mm})$, station $47,38^{\circ} 18^{\prime} \mathrm{N}, 146^{\circ} 35^{\prime} \mathrm{E}$, layer 0-100 m, August 29; R/V "Kavalerovo", 1980 - female N1196 $(1.25 \mathrm{~mm})$, station $52,35^{\circ} 43^{\prime} \mathrm{N}, 143^{\circ} 40^{\prime} \mathrm{E}$, layer 0-100 m, August 30; male N1197 (1.22 mm), station $58,34^{\circ} 29^{\prime} \mathrm{N}, 140^{\circ} 45^{\prime} \mathrm{E}$, layer $0-100 \mathrm{~m}$, September 1 ; female $(1.25 \mathrm{~mm})$, station $52,35^{\circ} 43^{\prime} \mathrm{N}, 143^{\circ}$ $40^{\prime} \mathrm{E}$, layer 0-100 m, August 30; male $(1.22 \mathrm{~mm})$, station $58,34^{\circ} 29^{\prime} \mathrm{N}, 140^{\circ} 45^{\prime} \mathrm{E}$, layer $0-100 \mathrm{~m}$, September 1; juvenile $(0.80 \mathrm{~mm})$, station $66,30^{\circ} 32^{\prime} \mathrm{N}, 140^{\circ} 39^{\prime} \mathrm{E}$, layer 0-100 m, September 4; juvenile $(0.82 \mathrm{~mm})$, station $71,30^{\circ} 58^{\prime} \mathrm{N}, 140^{\circ} 11^{\prime} \mathrm{E}$, layer $0-100 \mathrm{~m}$, September 4; juvenile $(0.76 \mathrm{~mm})$, station $74,33^{\circ} 02^{\prime} \mathrm{N}, 139^{\circ} 01^{\prime} \mathrm{E}$, layer $0-100 \mathrm{~m}$, September 5 .

\section{Remarks}

This species was described from the North Atlantic (Claus, 1890, 1891). Its first description includes only brief morphological information. Angel (1982) investigated the morphology of $H$. pelagica collected by R/V Discovery from many regions of the North Atlantic, in detail with taking into account of a literary data. As a result of comparison of our and Angel's specimens were found some differences, which are listed below (in brackets is for Angel's specimens).

Adult male. The height of the shell is $65-67 \%(69 \%)$ and the breadth is $63-65 \%(57 \%)$ of the length. The length of the capitulum of the frontal organ is $19-21 \%(22 \%)$ the length of the shell. The dorsal seta of the 1st antenna is covered with dense short hairs (almost bare), the dorsal margin on the 2nd segment of this limb is sharply curved (straight). The protopodite and exopodite borne on the 2nd antenna are subequal in length (protopodite is slightly longer). The seta " $\mathrm{b}$ " and "d" on the endopodite of this limb are subequal in length, seta "c" is shorther than "b" and longer than "a" setae (setae "c" and "d" are considerably longer than seta "b"), and seta "g" is longer than protopodite (seta "g" and protopodite are subequal in length). On the terminal segment of the mandible 2 ventrolateral short setae are pectinated (unnoticed). The seta bears on the exopodite of this limb is short and does not reache to the suture between the 1 st and 2 nd endopodite segments (extends beyond this suture). The posterior surface on the 1st endopodite segment of the maxilla is armed with 4 setae ( 6 setae), the 1st endite of this limb bears one short seta (one short and one middle in length setae), and the 2nd endite carries on long, one middle in length and one short setae (only one long seta). The endopodite of the sixth limb has 2 setae (one seta). The copulatory appendage is broader (is narrower).

Adult female. The height of the shell is $72-76 \%(81 \%)$ and the breadth is $73-74 \%(68 \%)$. The length of the capitulum of the frontal organ is $18-19 \%$ (20\%) the length of the shell. Most of the characteristic features of the 1 st and 2 nd antennae, mandible, maxilla and 5th limb are very similar to those of the male. On the ventrolateral surface of the 1st endopodite segment of the mandible are inserted 2 setae ( 3 setae). The length of the unpaired bristle and 7th pair of the claws on the caudal furca are about 45 and $20 \%$ (30\% both) the length of the 1st pair of the claws, respectively.

\section{Distribution}

Circumtropical - subtropical interzonal species (term "interzonal species" was introduced by Vinogradov, 1968: pp.50-52). It widely inhabits shallow and deep waters in the tropical and subtropical regions of the all oceans. In the West Atlantic (boundary between West and East Atlantic conditionally in drawn on $30^{\circ} \mathrm{W}$ ) this species was caught in latitude range $37^{\circ} \mathrm{N}-32^{\circ} \mathrm{S}$ (Vavra, 1906; Skogsberg, 1920; Deevey, 1968; 1974; Poulsen, 1969a; Ramires and Moguilevsky, 1971; Angel, 1979; 1982a), and the East Atlantic it was occured between $37^{\circ} \mathrm{N}$ and $28^{\circ} \mathrm{S}$ (Claus, 1890 ; 1891; Brady and Norman, 1896; Müller, 1906a; Angel, 1968; 1969; Poulsen, 1969a) in the depth range 0-1500 (2000) m. Besides that, Halocypris brevirostris (Granata and Caporiacco, 1949; Poulsen, 1969b; 
Deevey, 1978b; Gonzales and Breman, 1982) and H. inflata (Müller, 1906b; 1908; 1912; Alcaraz et al., 1975; Deevey, 1982b) were indicated for this ocean. Since these publications do not contain information about morphology of named species, their membership to $H$. pelagica is not able correctly to ascertain.

H. pelagica is known also for the Indian Ocean from the latitude range 5-28 ${ }^{\circ} \mathrm{S}$ (Cleve, 1905; ? Müller, 1906a; Poulsen, 1969a). In addition, Müller (1908) and Leveau (1967, 1969) indicated ostracods as H. inflata, and Georg and Nair (1980) as H. brevirostris for this ocean. However, data about morphology of these species is absent in the listed works, and therefore, we can not correctly ascribe them to $H$. pelagica.

In the Pacific Ocean $H$. pelagica lives in wide latitude range. Thus, in the East Pacific this species was collected between $42^{\circ} \mathrm{N}$ and $42^{\circ} \mathrm{S}$ (Brady, 1897; Poulsen, 1969a; Chavtur, 1976; 1992; Hanai et al., 1977; 1979; Tseng, 1980; Chen et al., 1983; Chen and Lin, 1991; 1994a; 1994b; 1994c, 1995), and in the West Pacific it was occured in the area $33^{\circ} \mathrm{N}-5^{\circ} \mathrm{S}$ (Juday, 1906; Poulsen, 1969a) in a layered catchs from surface to $4000 \mathrm{~m}$ (most numerous in the depth 0-200 (500) $\mathrm{m}$ ). Also, there are some records of $H$. inflata (Müller, 1906b; Hanai, 1959; Chen, 1982; Deevey, 1983) and $H$. brevirostris (Tseng, 1970a; 1970b; Haury, 1976) in the Pacific Ocean. However, these papers are without its morphological data, and thus taxonomical status of noted species is unelucidated.

Our original material was found in the West Pacific in the ranges $21-42^{\circ} \mathrm{N}$ and $138-152^{\circ} \mathrm{E}$, in layered catchs from surface to $500 \mathrm{~m}$, and in the East Pacific this species was collected between 33 $35^{\circ} \mathrm{N}$ and $127-139^{\circ} \mathrm{W}$ in the depth $0-200 \mathrm{~m}$.

\section{Sizes}

The length of males of $H$. pelagica from the Atlantic Ocean changes from $0.95 \mathrm{~mm}$ (Skogsberg, 1920; Deevey, 1968) to $1.26 \mathrm{~mm}$ (Angel, 1982a), and females from $1.00 \mathrm{~mm}$ (Angel, 1979; 1982a) to $1.40 \mathrm{~mm}$ (Claus, 1890; 1891; Angel, 1979; 1982a). Sizes of this species for the Indian Ocean are unknown. Males from the Pacific Ocean have length range from $1.05 \mathrm{~mm}$ (Chen et al., 1983) to 1.42 $\mathrm{mm}$ (Chen and Lin, 1995) and females - from 1.16 to $1.40 \mathrm{~mm}$ (Chen et al., 1983).

Our specimens of males and females of $H$. pelagica from Pacific Ocean - 1.12-1.30 mm and 1.20$1.43 \mathrm{~mm}$, respectively.

\section{Halocypris inflata (Dana, 1849)}

Conchoecia brevirostris + C. inflata Dana, 1849: 52.

Halocypris inflata + H. brevirostris Dana, 1853: 1301, 1303, Pl. 41, Fig. 8, 9, Pl. 91, Fig. 9a-c.

Halocypris concha Claus, 1874a: 177; 1874b: 7, Pl. 2, Figs. 20-25, Pl. 3, Figs. 26-35; 1890: 2425; 1891: 77, Pl. 8, Fig. 12, Pl. 11, Figs. 6, 7, Pl. 22, Figs. 1-12, Pl. 24, Figs. 6-20, Pl. 26, Fig. 1; Brady and Norman, 1896: 702-703, Pl. 62, figs. 14-19; Scott, 1905: 370; Vavra, 1906: 63-64.

Halocypris brevirostris: Brady, 1880: 166, Pl. 39, figs. 1-11; Skogsberg, 1920: 584-601, figs. 112-115; 1931: 9; Poulsen, 1969a: 65 (part) (stations 3908, 4781 and 4788, males in length range 1.4$1.5 \mathrm{~mm}$ and females 1.5-1.8 mm), 66 (part), 25 Fig. (for "Atlantic", "Indian" and part "W. Pacific"), table 8 (for females in 1.5-2.02 mm from: "Atlantic" $-11^{\circ} \mathrm{N}-11^{\circ} \mathrm{S}, 27^{\circ}-29^{\circ} \mathrm{N}$ ), table 9 (for males in 1.4-1.5 mm from: "Atlantic-Indian" - $4^{\circ} \mathrm{N}-28^{\circ} \mathrm{S}$, "Pacific" - $26^{\circ}-33^{\circ} \mathrm{N}, 33^{\circ}-42^{\circ} \mathrm{S}$, "E. Pacific" - $12^{\circ}$ $22^{\circ} \mathrm{S}$ ); Moguilevsky and Angel, 1975: 296-297 (part ?); Deevey, 1970: 804; 1974: 358-359 (part), 1978a: 50; Chavtur, 1977a: 30 (part); 1977b: 20 (part); Hanai et al., 1977: 81-82 (part); Angel, 1979: 75, 76 (only specimens taken in a neuston at 30(N-23( W); Hanai et al., 1980: $53-55$ (part); Tseng, 1980: 405, 415, 416, Fig. 8.

Halocypris dubia var. major Müller, 1890: 269, Taf. 28, Fig. 19, 23, 24, 30, 35

? Halocypris concha: Brady, 1897: 97.

Halocypris inflata: Müller, 1906a: 50-51 (part), Taf. 7, Fig. 19-28; 1912: 58-59 (part); Deevey, 1982a:133; Martens, 1979: 311-314, Abb. 5, 6; 1981: 68, 69, 77, 78, tables 1, 2; Angel, 1982: figs. 3, 
$4,9,11,14$, tables $1-3$.

Halocypris pelagica + H. globosa: Scott, 1912: 587, Pl. 13, Figs. 29-32.

? Halocypris inflata + H. toynbeeana: Lubbock, 1860: 188, 189, pl. 29, figs. 35-39.

? Halocypris inflata: Müller, 1906b: 3, 1908: 65; Iles, 1953: 270;

\section{Material examined}

R/V "Vityaz" 20th cruise, 1955 - female $(1.60 \mathrm{~mm})$ and 2 juveniles $(1.00-1.15 \mathrm{~mm})$, station 3226 , $37^{\circ} 39^{\prime} \mathrm{N}, 144^{\circ} 30^{\prime} \mathrm{E}$, layer $150-1000 \mathrm{~m}$, May 2 ; female $(1.50 \mathrm{~mm})$ and juvenile $(1.10 \mathrm{~mm})$, same station, layer 200-500 m; R/V "Orlyk" 1967 - female (deformed) and 2 juveniles (1.08-1.18 mm), 31 $55^{\prime} \mathrm{N}, 138^{\circ} 11^{\prime} \mathrm{E}$, layer 0-100 m, May 16; R/V "Vityaz" 45th cruise, 1969 - juvenile (1.30 mm), station 6151, sample, $285,37^{\circ} 38^{\prime} 6 \mathrm{~N}, 143^{\circ} 51^{\prime} 5 \mathrm{E}$, layer 2000-2500 m, June 29; R/V "Orlyk" 1972 - female $(1.65 \mathrm{~mm}), 1972(1.65 \mathrm{~mm})$, station 34 , sample $68,30^{\circ} 00^{\prime} \mathrm{N}, 145^{\circ} 00^{\prime} \mathrm{E}$, layer 0-25 m, August 20; R/V "Pelamida" 1974 - male N2023 (1.53 mm) and female N2024 (1.76 mm), station 58, sample 30, 38 $00^{\prime} \mathrm{N}, 149^{\circ} 00^{\prime} \mathrm{E}$, layer 50-100 m, May 29; R/V "Seskar" 1975 - 3 female (1.60-1.65 mm), station 33, sample $84,33^{\circ} 29^{\prime} 5 \mathrm{~N}, 141^{\circ} 28^{\prime} 0 \mathrm{E}$, layer 0-100 m, July 29; female (1.63 mm), R/V "Seskar" 1975 female N2025 (1.48 mm), station 96, sample $121,30^{\circ} 00^{\prime} \mathrm{N}, 138^{\circ} 00^{\prime} \mathrm{E}$, layer 0-100 m, August 28; station 102, sample $115,23^{\circ} 58^{\prime} \mathrm{N}, 138^{\circ} 15^{\prime} \mathrm{E}$, layer 0-100 m, August 15; R/V "Pelamida" 29th cruise, 1976 - female (1.62 mm), station 114 , sample $156,23^{\circ} 00^{\prime} \mathrm{N}, 138^{\circ} 14^{\prime} \mathrm{E}$, layer $800-1000 \mathrm{~m}$, June 6: R/V "Pelamida" 30 cruise, 1976 - male N2026 (1.42 mm), station 100(91), sample $143,26^{\circ} 00^{\prime} \mathrm{N}, 138^{\circ} 00^{\prime} \mathrm{E}$, layer 0-100, September 1.

\section{Remarks}

For the first time this species was described and figured (Dana, 1849; 1853) from samples collected in south-western Atlantic $\left(23^{\circ} 00 \mathrm{~S}\right.$ and $\left.41^{\circ} 10 \mathrm{~W}\right)$. The detailed description of its morphology has been given by Skogsberg (1920) based on the materials from this region $\left(15-19^{\circ} \mathrm{S}\right.$ and $\left.34-37^{\circ} \mathrm{W}\right)$ and from the North Atlantic $\left(1-30^{\circ} \mathrm{N}\right.$ and $\left.20-29^{\circ} \mathrm{W}\right)$. Most of the characteristic features of the shell and limbs in our specimens collected from the north-western Pacific are very similar to those in the Skogsberg's description. There are following differences between Pacific and Atlantic specimens only in females (in brackets from Skogsberg's description): a peg-like process of the end segment of the endopodite on the 2nd antenna is not fixed between the " $\mathrm{h}$ " and "i" setae (with a peglike process), the dorsal setae on the 1st and 2nd segments of the exopodite of the 5th limb extended barely (considerably) the terminal margin of this limb, the distodorsal and distoventral setae placed on the 1st segment of the 6th limb extended barely (considerably) the terminal margin of this limb. Besides that, in both sexes the anterior surface of the endopodite of the maxilla bears only 4 setae, whereas there are 6 setae in the Skogsberg's description.

\section{Distribution}

Circumtropical - subtropical interzonal species (term "interzonal species" was introduced by Vinogradov, 1968: pp. 50-52). It widely inhabits shallow and deep water in the tropical and subtropical regions of the all oceans. In the Atlantic Ocean this species was occurred in the latitude range $60^{\circ} \mathrm{N}-42^{\circ} \mathrm{S}$ from surface to $1000 \mathrm{~m}$ and rarely deeper (Dana, 1849; 1853; ? Lubbock, 1860; Claus, 1874a; 1874b; 1890; 1891; Brady, 1880; ? 1897; Brady and Norman, 1896; Vavra, 1906; Scott, 1912; Müller, 1906a; 1912; Skogsberg, 1920; 1931; ? Illes, 1953; Moguilevsky and Angel, 1975; Angel, 1979; 1982; Poulsen, 1969a; Deevey, 1970; 1974). Besides that, in the row publications were indicated H. inflata (Müller, 1906b; 1908; Alcaraz et al., 1975; Deevey, 1982b) and H. brevirostris (Granata and Caporiacco, 1949; Poulsen, 1969b; Deevey 1978b; Gonzales and Breman, 1982) for this ocean. Since, these publications do not contain information about morphology of the named species, that their membership to $H$. inflata is not able correctly to ascertain.

$H$. inflata is known also for the Indian Ocean from the Island Shri-Lanka to $36^{\circ} \mathrm{S}$ (Brady, 1880; Scott, 1905; M(ller, 1906a; 1912; Poulsen, 1969a) in shallow waters and also in a vertical tows from 
2000-3000 m to surface. In addition Müller (1908) and Leveau $(1967,1969)$ indicated ostracods as $H$. inflata, and Georg and Nair (1980) as H. brevirostris for this ocean. However, data on morphology of these species is absent in listed works, and therefore, we can not correctly ascribe to $H$. inflata.

In the Pacific Ocean H. inflata lives in wide latitude range. Thus, in the East Pacific this species was found between $35^{\circ} \mathrm{N}$ and $42^{\circ} \mathrm{S}$ (Brady, 1880; Müller, 1890; Brady and Norman, 1896; Poulsen, 1969a; Chavtur, 1977a; 1977b; 1992; Hanai et al., 1977; 1980; Tseng, 1980), and in the West Pacific it was collected in the area $33^{\circ} \mathrm{N}-42^{\circ} \mathrm{S}$ (Claus, 1874a; 1874b; Poulsen, 1969a; Deevey, 1978; Martens, 1979 ; 1981) in the depth range $0-2000 \mathrm{~m}$, but most numerous in layer 0-200(500) $\mathrm{m}$. Also, there are some records of $H$. inflata (Müller, 1906b; Hanai, 1959; Chen, 1982; Deevey, 1983) and $H$. brevirostris (Tseng, 1970a; 1970b; Haury, 1976) in the Pacific Ocean. However, these papers are without its morphological data, and thus taxonomical status of noted species is unelucidated.

In the South Ocean $H$. inflata was caught only near its northern boundaries, where warm watermasses are located; in the its Indian sector to $54^{\circ} \mathrm{S}$ on the south in the depth range 0-2500 $\mathrm{m}$ (Deevey, 1982a), and in the Pacific sector it occurs to $49^{\circ} \mathrm{S}$ in the depth 0-2000 m (Brady, 1880; Deevey, 1978a). Besides that, Deevey (1983) noted H. inflata in the ostracod list for the region $35-47^{\circ} \mathrm{S}$ in layer $0-1000 \mathrm{~m}$. However, additional information about its morphology is need for confirmation of membership to discussed species.

Our original material was collected in the Pacific Ocean in the area $23^{\circ}-39^{\circ} \mathrm{N}$ and $136^{\circ}-149^{\circ} \mathrm{E}$ in a layered catchs from surface to $2500 \mathrm{~m}$ (most numerous in layer $0-200 \mathrm{~m}$ ), and in region $13^{\circ} \mathrm{N}-92^{\circ} \mathrm{W}$ in layer $200-500 \mathrm{~m}$.

Size

The length of males of $H$. inflata from the Atlantic Ocean changes from $1.32 \mathrm{~mm}$ (Angel, 1982) to $1.60 \mathrm{~mm}$ (Dana, 1853; Skogsberg, 1920; Angel, 1982, 1993) and females are from $1.48 \mathrm{~mm}$ (Angel, 1982) to $2.02 \mathrm{~mm}$ (Poulsen, 1969a). In the Indian Ocean (and Indian sector of the South Ocean) males have length range 1.40-1.54 mm (Deevey, 1982a) and females are 1.40-1.70 mm (Deevey, 1982a), and in the Pacific Ocean (and Pacific sector of the South Ocean) the length for males are 1.36-1.57 mm (Martens, 1979) and for females are from $1.51 \mathrm{~mm}$ (Martens, 1979) to $1.80 \mathrm{~mm}$ (Tseng, 1980).

Our specimens of males and females of H. inflata from the Pacific Ocean the length of males and females are $1.42-1.53 \mathrm{~mm}$ and $1.48-1.76 \mathrm{~mm}$, respectively.

\section{Genus Felia Poulsen, 1969}

This genus contains $F$. cornuta (Müller, 1906), F. bicornis (Müller, 1906) and F. dispar (Müller, 1906). Only F. cornuta and F. bicornis were caught by Russian expeditions in the North Pacific.

Key to Species of Genus Felia (from Poulsen, 1969a)

Shell valves anteroventrally with a round verruca; shoulder-vault very strongly developed with a round dorsally projecting process anteriorly of the basis of the spine

Felia bicornis (Müller, 1906)

Shell valves without verruca; shoulder-vault only evenly arched dorsally Felia cornuta (Müller, 1906)

\section{Felia cornuta (Müller, 1906)}

(Figs. 11 and 12)

Halocypris cornuta var. typica Müller, 1906a: 18, Taf. 5, Fig. 8, 9, Taf. 8, Fig. 1-3, 5-7; 1906b: 3; 1908: 65.

Halocypris cornuta cornuta Müler, 1912: 58.

Felia cornuta: Poulsen, 1969a: 78-89, figs. 33-37: 1969b: 145, 146, fig. 7; 1977: 5; Deevey, 


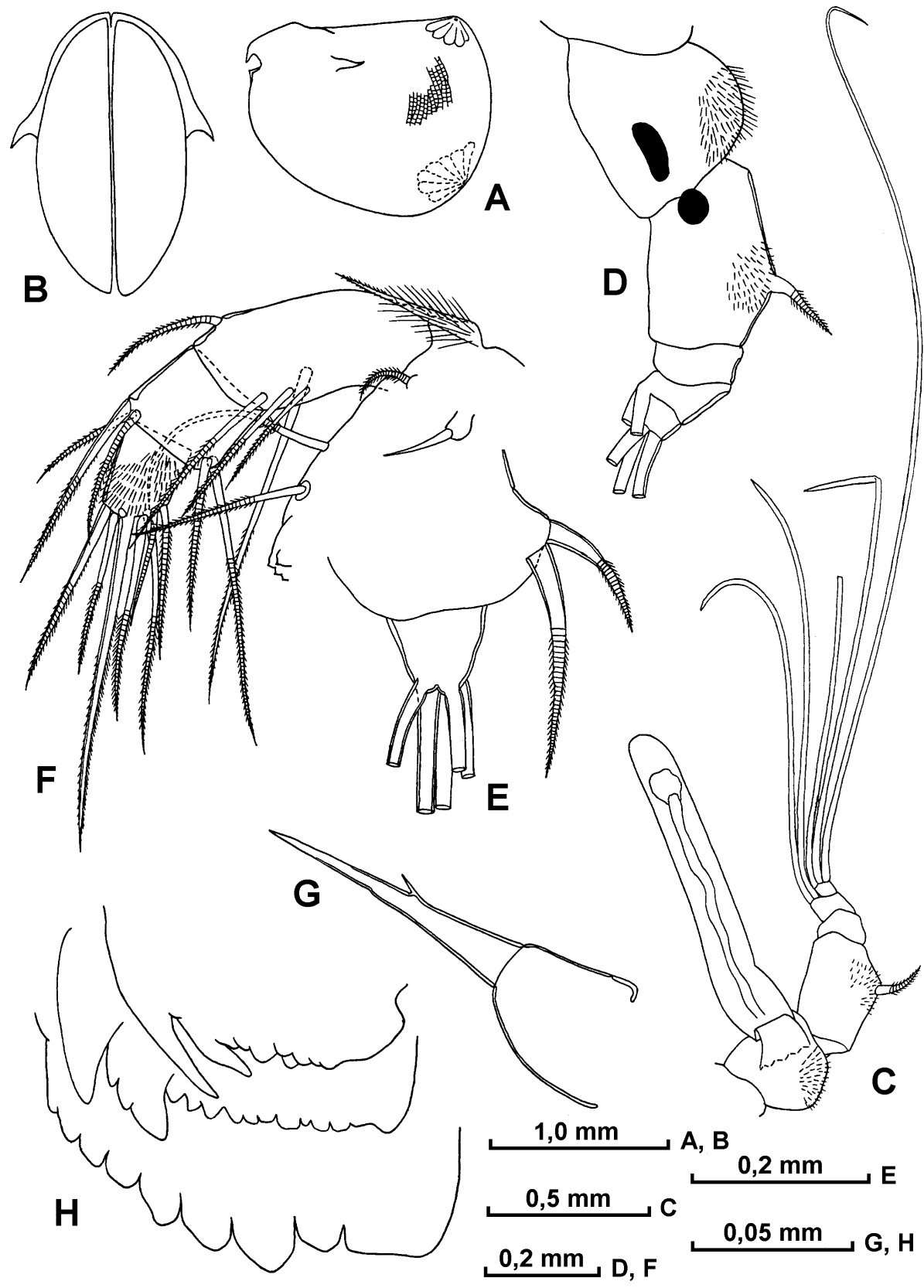

Fig. 11. Felia cornuta (female: R/V Vityaz, 1969 - St. 6151, sample 287) A - left valve of shell with lateral view, B - shell with ventral view, C - frontal organ and 1st antenna, D - 1st antenna, E - endopodite of 2nd antenna, $\mathrm{F}$ - mandible, $\mathrm{G}$ - epipodite of mandible, $\mathrm{H}$ - tooth edge, distal and proximal tooth rows on coxale of mandible. 


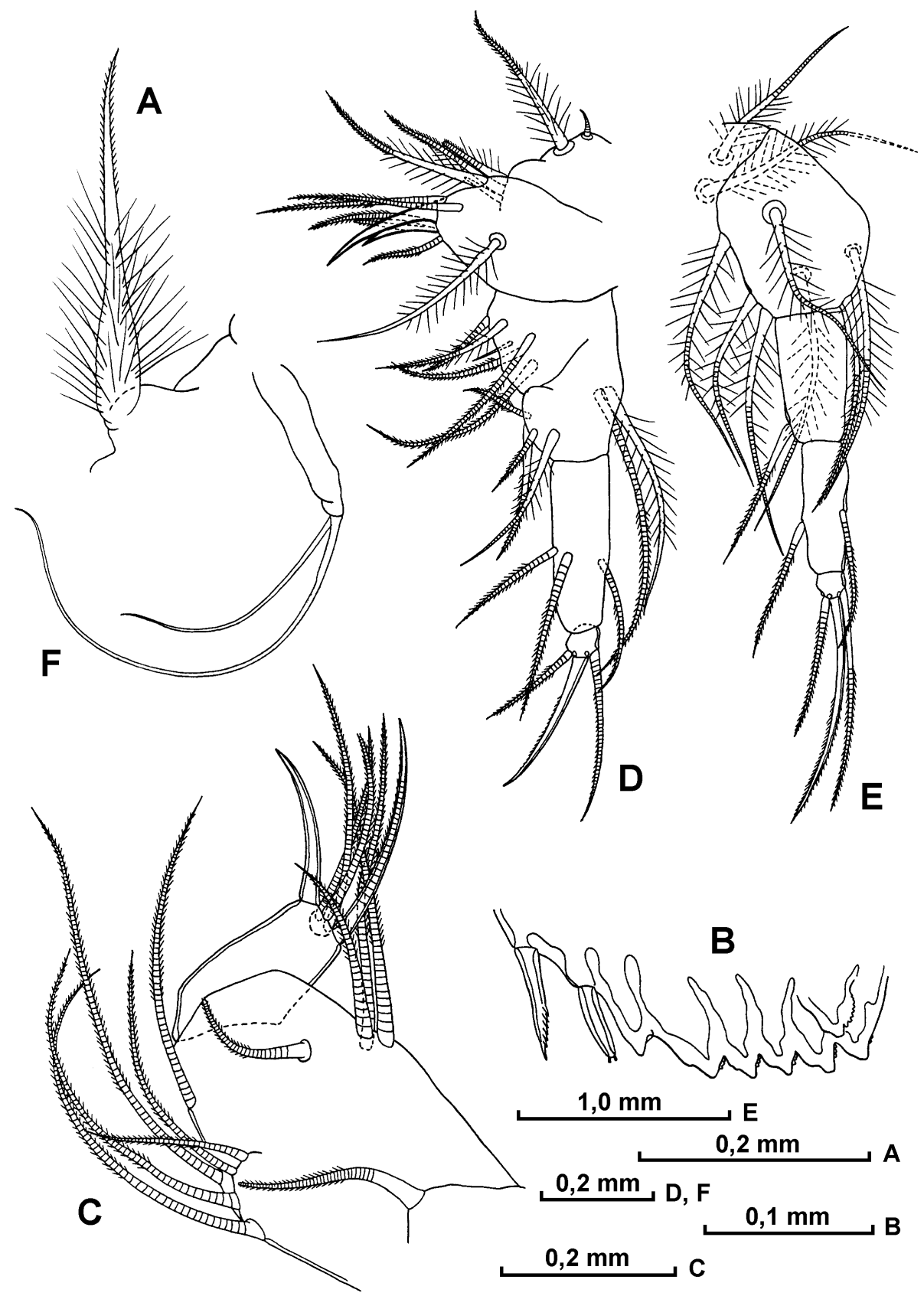

Fig. 12. Felia cornuta (female: R/V Vityaz, 1969 - St. 6151, sample 287) A - endopodite of mandible, B - basal endite of mandible, C - maxilla, D - 5th limb, E - 6th limb, F - 7th limb. 
1982a: 133, 134, 135, 136; Hanai et al., 1977: 82; Hanai et el., 1980: 56-57; Chen et al., 1983: 90, fig. 8; Yin et al., 1991: 87.

Felia cornuta cornuta: Chavtur, 1977a: 30; Deevey, 1978a: 45, 50; 1978b: 54, 67, 68; Chen, Lin, 1995: 54, fig. $61(1,2)$.

\section{Material examined}

R/V "Vityaz" 20th cruise, 1955 - juvenile (length $1.60 \mathrm{~mm}$ ), station $3238,36^{\circ} 11^{\prime} \mathrm{N}, 155^{\circ} 10^{\prime} \mathrm{E}$, layer 200-500 m, May 9; immature female $(2.50 \mathrm{~mm})$ and immature male $(2.40 \mathrm{~mm})$, station 3241 , $38^{\circ} 17^{\prime} \mathrm{N}, 157^{\circ} 39^{\prime} \mathrm{E}$, layer 234-562 m, May 10; R/V "Vityaz" 45th cruise, 1969 - female and male (deformed), station 6151 , sample $287,37^{\circ} 38^{\prime} 6 \mathrm{~N}, 143^{\circ} 51^{\prime} 5 \mathrm{E}$, layer $750-1000 \mathrm{~m}$, June 29 ; male (3.50$3.60 \mathrm{~mm}$ are lost) and female $(4.05 \mathrm{~mm})$, same station, sample 283 , layer $1000-1500 \mathrm{~m}$; R/V "Pelamida" 1974 - 2 immature females ( $2.60 \mathrm{~mm}$, other specimen is deformed), station $58,38^{\circ} 00^{\prime} \mathrm{N}$, $149^{\circ} 00^{\prime} \mathrm{E}$, layer 800-1000 m, May 29; 3 immature females (2.45-2.6 mm), same station, layer 600-800 $\mathrm{m}$; immature female $(2.50 \mathrm{~mm})$, station $69,33^{\circ} 30^{\prime} \mathrm{N}, 149^{\circ} 00^{\prime} \mathrm{E}$, layer $800-1000 \mathrm{~m}$, June 1 .

\section{Remarks}

Müller (1906a) gave a brief description for $F$. cornuta for the first time. Same literature include information only on the shell, frontal organ and 1st and 2nd antennae (Chen et al., 1983; Chen and Lin, 1995). Only Poulsen (1969a) described and illustrated this species in detail.

Our specimens of the females (males are deformed or lost) somewhat differ from previous descriptions in following respects: the height of the shell is about $80 \%$ of the length (approximately $85 \%$ in Müller, 1906, about 75\% in Chen et al., 1983, 77\% in Chen and Lin, 1995, and 66-82\% in Poulsen, 1969a), and its anterodorsal horns are smaller than those noted in Müller's description (Taf. 8, Fig. 3). The frontal organ is broader (narrower in Müller, 1906: Taf. 8, Fig. 6; Poulsen, 1969a: Fig. 33a; Chen and Lin, 1995: Fig. 61.2). The dorsal side on the 1st segment of the 1st antenna is strongly convex (straight in Müller, 1906: Taf. 8, Fig. 7; Poulsen, 1969a: Fig. 33b, c), the dorsal seta placed on the 2nd segment is approximately 60\% the height of it (90-100\% in Müller, 1906 and $75 \%$ in Poulsen, 1969a, figures are such), the 2nd segment is undivided by suture (diveded in Poulsen, 1969a: 82, Fig. $33 \mathrm{~b}$ ), only dorsal surface on the 1st and 2nd segments of this limb are covered with hairs (dorsal and ventral surface in Poulsen, 1969a: Fig. 33a-c). Dorsal margins of the 1st and 2nd segments on the endopodite of the 2 nd antenna are placed at an angle of about $45^{\circ}$ (without angle in M(ller 1906: Taf. 8, Fig. 5; Poulsen, 1969a: Fig. 33e), there is no hairs on the 1st segment (hairs are present in Poulsen, 1969a: 82, Fig. 33e), the seta "a" of this segment is approximatelly $60 \%$ the length of the seta "b" (about 50\% in Müller, 1906 and 70\% in Poulsen, 1969a, figures are such, and 60-70\% in Chen et al., 1983: Fig. 8e). The surface on the 1st segment of the 2nd antenna is uncovered with hairs (covered in Poulsen, 1969a and Chen et al., 1983, figures are such).

Differences are listed below only between our females and Poulen's specimens (in brackets for Poulsen, 1969a): the seta on the exopodite of the mandible is very thick at its base (usual seta); the anterodorsal seta on the basale of this limb is about $1 / 4$ the length of the 1 st segment on its endopodite (about 1/2 the length - Fig b. $33 \mathrm{~h}, \mathrm{i}$ ). The length of the basal seta inserted on the maxilla is short and about $85 \%$ the height of its endopodite (seta and height of endopodite are subequal - Fig. 34a); the 1st segment of the endopodite is armed with 4 long and 2 short anterior, and one lateral setae (with 4-5 subequal setae and without lateral setae - p. 82-83, Fig. 34a); on the 2nd segment of this limb anterior claw is shorter than posterior claw (both subequal - figures are such), and central claw and 2 subterminal setae on this segment are long (short - figures are such). The 2 nd endite on the protopodite of the maxilla bears 2 long and one short setae (only 2 long setae - p. 83, Fig. 34e). On the 1 st segment of the endopodite of the 6th limb are placed 7 setae, of which 6 plumose $(6$ setae,of which 4 plumose - p. 83, Fig. 34f); all these setae, except of the distodorsal seta, are longer than those in Poulsen's description. The short seta on the 7th limb is considerably longer than that of this limb (about subequal - Fig. 34g). 


\section{Distribution}

Circumtropical - subtropical bathypelagic species. It inhabits deep-sea zone of the tropical and subtropical regions of three oceans. In the East Atlantic (boundary between East and West Atlantic conditionally is drawn on $30^{\circ} \mathrm{W}$ ) Felia cornuta was occured in the area $14^{\circ} \mathrm{N}-36^{\circ} \mathrm{S}$ and $13^{\circ} \mathrm{E}-22^{\circ} \mathrm{W}$ in a vertical tows from $4000 \mathrm{~m}$ to 0-600 m (Müler, 1906a; 1908; Poulsen, 1969a; 1969b), and in the West Atlantic it was noted only for the region $11-12^{\circ} \mathrm{N}$ and $65-66^{\circ} \mathrm{W}$ in a vertical tows $1000(1200)-0 \mathrm{~m}$ (Deevey, 1978b). In the Indian Ocean $F$. cornuta was caught between $5^{\circ} \mathrm{N}-4^{\circ} \mathrm{S}$ and $62^{\circ}-96^{\circ} \mathrm{E}$ in a vertical tows 2000(2500) - $0 \mathrm{~m}$ and 1100(1200) - $0 \mathrm{~m}$ (Müller, 1906a; Poulsen, 1969a). In the East Pacific it was found from the Japan (Misaki, approximately $40^{\circ} \mathrm{N}$ ) to $34^{\circ} \mathrm{S}$ and between $111-178^{\circ} \mathrm{E}$ in the main in a vertical tows 2000-0(75) m (Müller, 1906b; Poulsen, 1969a; Chen et al., 1983; Chen and Lin, 1995), and in the West Pacific with species was occurred in the area $7^{\circ} \mathrm{N}-13^{\circ} \mathrm{S}$ and $78-176^{\circ} \mathrm{W}$ in the depth 50(75)-500(2000) $\mathrm{m}$ (Poulsen, 1969a). In the South Ocean $F$. cornuta was caught in the region $40^{\circ} \mathrm{S}-15^{\circ} \mathrm{E}$ (Atlantic sector) in a vertical tow 1500-0 $\mathrm{m}$ (Müller, 1906a), and also between 41$51^{\circ} \mathrm{S}$ and $150^{\circ} \mathrm{E}-159^{\circ} \mathrm{W}$ (Pacific sector) in the depth 75-750(1000) $\mathrm{m}$ and 500(750)-1000(2500) $\mathrm{m}$ (Poulsen, 1969a; Deevey, 1978a; 1982a).

Our original material came from the region $33^{\circ}-38 \mathrm{~N}$ and $143-157^{\circ} \mathrm{E}$ in the depth $200-1500 \mathrm{~m}$.

Sizes

Müller (1906a) described the length for males and females as 3.1-3.25 mm and 3.2-3.5 mm, respectively. Poulsen's (1969a) specimens have following length range: males 3.0-3.4 mm and females 3.0-3.7 mm. Deevey (1978a; 1978b; 1982a) noted the length for male as $2.65 \mathrm{~mm}$ and for females as $2.65-2.80 \mathrm{~mm}$.

The length of the our specimens of males are 3.5-3.6 mm and female is $4.05 \mathrm{~mm}$.

\section{Felia bicornis (Müller, 1906)}

(Figs. 13-15)

Halocypris bicornis Müller, 1906a: 49-50, Taf. 8, Fig. 8-12, 17, 1908: 65; 1912: 58.

Halocypris taurina Vavra, 1906: 66-67, Taf. 7, Fig. 128-132a.

Felia bicornis: Poulsen, 1969a: 89-94, figs. 38-40; 1977: 5; Deevey, 1970: 804, fig. 2; 1978b: 67, 68; 1982b: 469, 470, 475, 476, figs. 6, 7; 1983: table 1; Chavtur, 1977a: 30; Hanai et al., 1980: 56; Chen, 1980: 65; Chen et al., 1983: 89, fig. 7; Yin et al., 1991: 88; Chen and Lin, 1995: 3, 53-54, figs. 5 (8), 60; 1994: table 2.

\section{Material examined}

R/V "Vityaz" 20th cruise, 1955 - juvenile (deformed), station $3238,36^{\circ} 11^{\prime} \mathrm{N}, 155^{\circ} 10^{\prime} \mathrm{E}$, layer 200-500 m, May 9; R/V "Vityaz" 29th cruise, 1958 - male (length $2.9 \mathrm{~mm}$ ), station $4183,40^{\circ} 01^{\prime} \mathrm{N}$, $127^{\circ} 39^{\prime} \mathrm{W}$, layer $200-500 \mathrm{~m}$, December 6; R/V "Vityaz" 57th cruise, 1975 - juvenile (1.7 mm), station $7260,5^{\circ} 38^{\prime} 0 \mathrm{~S}, 130^{\circ} 48^{\prime} 3 \mathrm{E}$, layer 200-300 m, March 18.

\section{Remarks}

Most descriptions of this species include data only for the shell, frontal organ, and 1st and 2nd antannae (Müller, 1906a; Vavra, 1906; Deevey, 1970; Chen et al., 1983; Chen and Lin, 1995), and only Poulsen's monography (1969a) and Deevey's paper (1982b) contain information for the other limbs.

Our male has some differences from previous descriptions as follows: the basal segment of the 1st antenna has not a longitudinal spiny ridge on the outer side (with a longitudinal spiny ridge in Deevey, 1982b: 478, Fig. 6d, f); the seta "d" on the endopodite of the 2 nd antenna is about $1 / 2$ the length of the seta "a" (setae "d" and "a" are subequal in Müller, 1906: Taf. 8, Fig. 11, 12; and 1/3 the length of the 


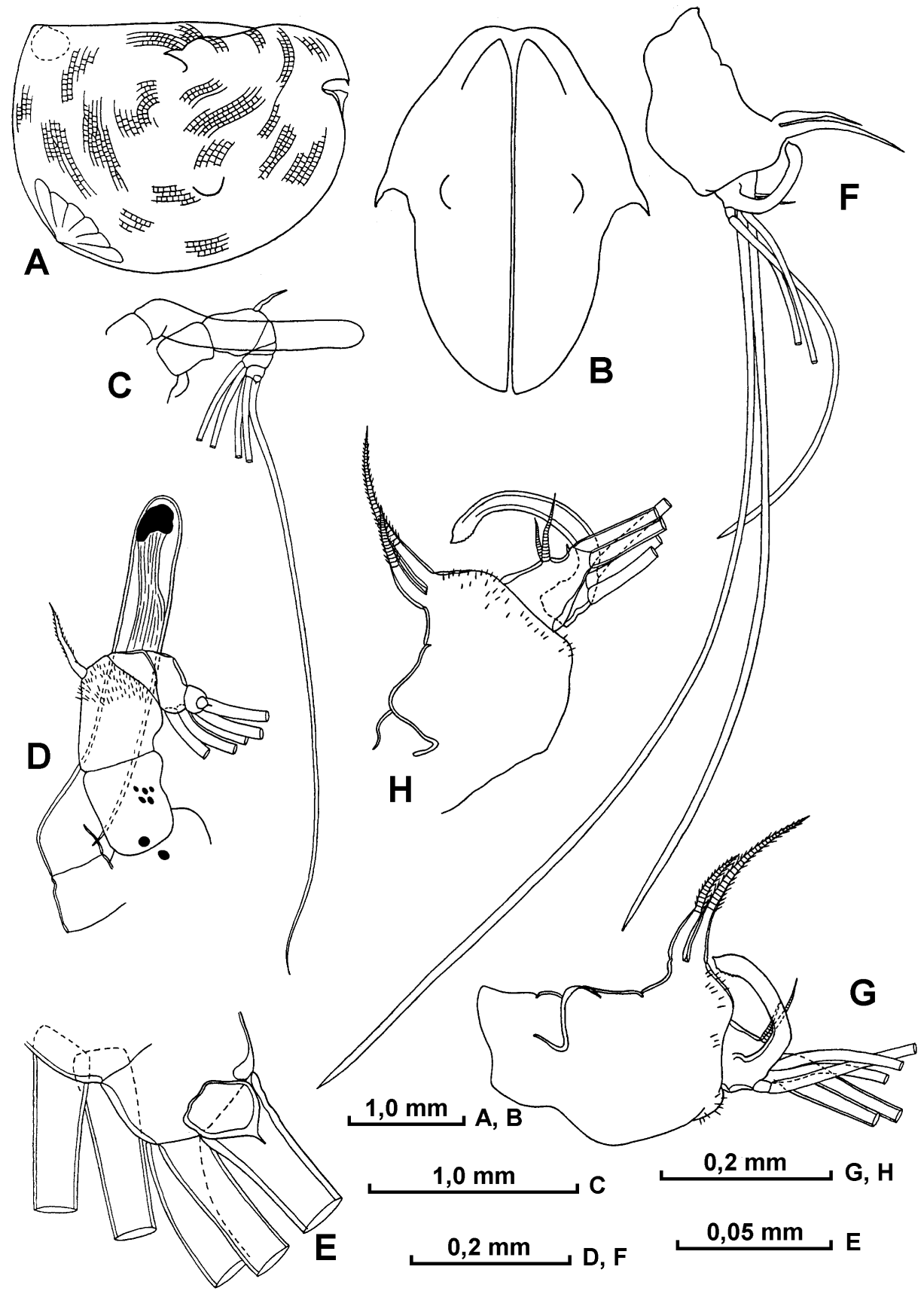

Fig. 13. Halocypris bicornis (male: R/V Vityaz, 1958 - St. 4183) A - right valve of shell with lateral view, B - shell with ventral view, C and D - frontal organ and 1st antenna, E - terminal part of 1st antenna, F and G - left endopodite of 2nd antenna, $\mathrm{H}$ - right endopodite of 2nd antenna. 
seta "a" in Poulsen, 1969a: Fig. 38b, d); the 1st segment on the maxilla bears 6 anterior and one lateral setae (only 4 anterior setae and without lateral seta in Poulsen, 1969a: 91) and without some distal spinules (with distal spinules in Deevey, 1982b: Fig. 7c); the distoventral seta on the endopodite of the 5 th limb is extended conciderably beyond the distal margin of the 1st exopodite segment (only reachs the distal margin in Deevey, 1982b: Fig. 7e); the 1st exopodit segment of the 6th limb is armed with 7 setae (6 setae in Poulsen, 1969: 91) the setae placed on its 2nd segment is extended to the terminal margin of this limb (is not extended in Deevey, 1982b: 7f).

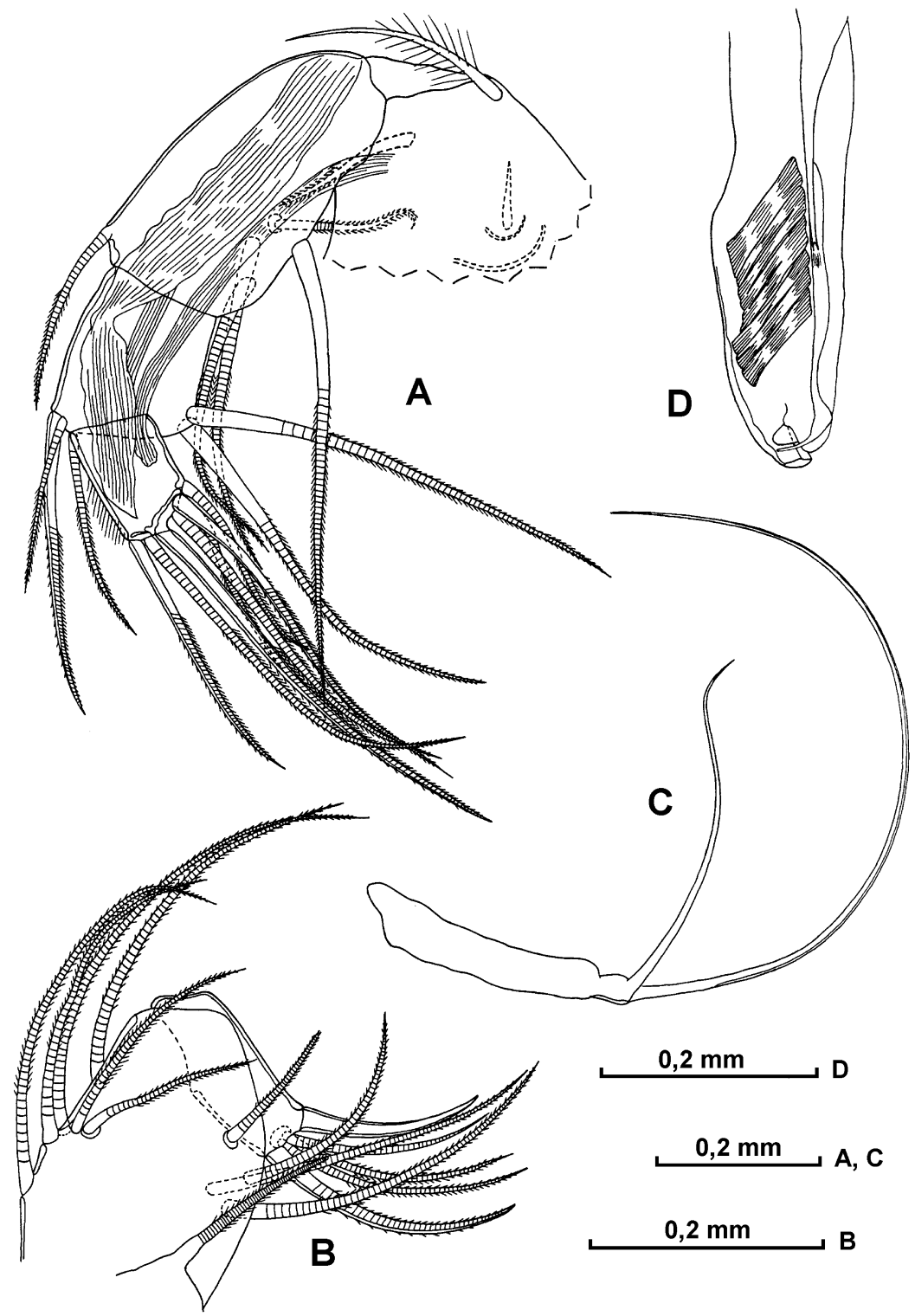

Fig. 14. Felia bicornis (male: R/V Vityaz, 1958 - St. 4183) A - mandible, B - maxilla, C - 7th limb, D - copulatory appendage. 


\section{Distribution}

Circumtropical - subtropical bathypelagic species. It lives in the deep-sea zone of the tropical and subtropical regions of three oceans. In the East Atlantic (boundary between East and West Atlantic conditionally in drawn on $30^{\circ} \mathrm{W}$ ) F. bicornis was found in the area $2^{\circ} \mathrm{N}-19^{\circ} \mathrm{S}$ and $3^{\circ} \mathrm{E}-20^{\circ} \mathrm{W}$, and also in the region $46^{\circ} \mathrm{N}-8^{\circ} \mathrm{W}$, mainly in a vertical tows from $3000 \mathrm{~m}$ to surface (Müller, 1906a; 1908; Vavra, 1906; Poulsen, 1969a). In the West Atlantic it occured between $15^{\circ} \mathrm{N}-3^{\circ} \mathrm{S}$ and $32^{\circ}-61 \mathrm{~W}$ in a vertical tows $1200-0 \mathrm{~m}$ and in a layered catchs from $75-150 \mathrm{~m}$ to $500-3000 \mathrm{~m}$ (Vavra, 1906; Poulsen,

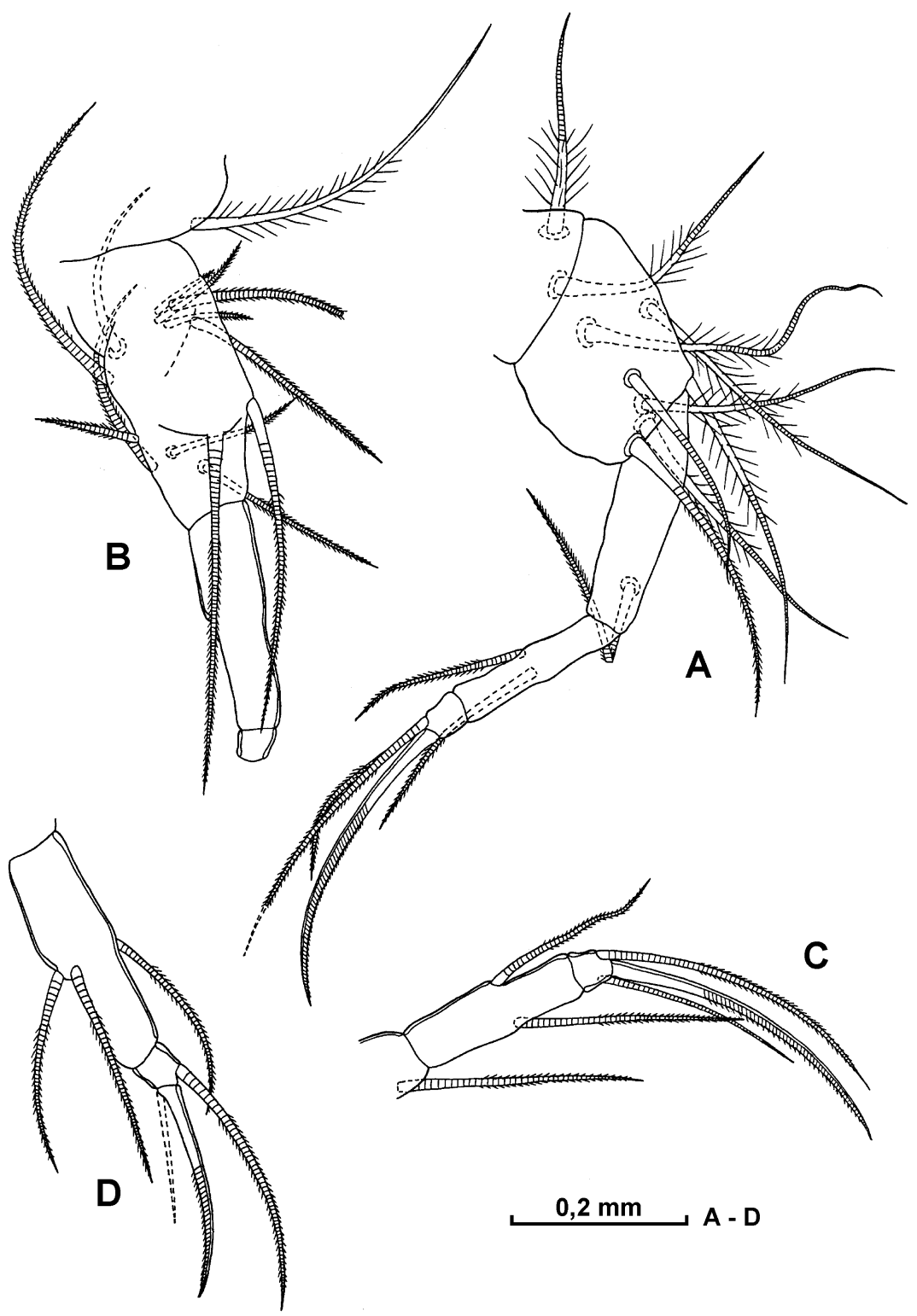

Fig. 15. Felia bicornis (male: R/V Vityaz, 1958 - St. 4183) A - 6th limb, B - 5th limb, C - distal part of 6th limb, D - distal part of 5th limb. 
1969a; Deevey, 1970; 1978b; 1982b). For the Indian Ocean F. bicornis is known from $7^{\circ}-12^{\circ} \mathrm{S}$ and $48-98^{\circ} \mathrm{W}$ in a layered catchs from $2000-2500 \mathrm{~m}$ to surface (Müller, 1906a; Poulsen, 1969a). In the East Pacific it was registered for the area $4^{\circ}-28^{\circ} \mathrm{S}$ and $116-177^{\circ} \mathrm{W}$ in the depth (50(75)-400(1500) $\mathrm{m}$ (Poulsen, 1969a), and in the West Pacific this species was caught between $24^{\circ} \mathrm{N}-7^{\circ} \mathrm{S}$ and $119^{\circ}-138^{\circ} \mathrm{E}$ in the depth range from 75-100 $\mathrm{m}$ to $1750 \mathrm{~m}$ (Poulsen, 1969a; Chen et al., 1983; Chen and Lin, 1995). In the South Ocean $H$. bicornis was found in the region $43^{\circ} \mathrm{S}-36^{\circ} \mathrm{E}$ (Indian sector) in a vertical tow 2500-0 $\mathrm{m}$ (M(ller, 1908), and also in $41^{\circ} \mathrm{S}-176^{\circ} \mathrm{E}$ (Poulsen, 1969a) and in $39^{\circ} \mathrm{S}$ (longitude is unknown) (Deevey, 1983) in layers 75-1250 $\mathrm{m}$ and 250-500 $\mathrm{m}$, respectively (Pacific sector).

Our original material came from the regions $36^{\circ} \mathrm{N}-155^{\circ} \mathrm{E}, 40^{\circ} \mathrm{N}-127^{\circ} \mathrm{W}$ and $5^{\circ} \mathrm{S}$ and $130^{\circ} \mathrm{E}$ in the depth 200-300(500) $\mathrm{m}$.

\section{Sizes}

Müller (1906a) recorded for male and female as equal length $1.83 \mathrm{~mm}$. Vavra's (1906) specimen of female has length $2.2 \mathrm{~mm}$. In the Poulsen's monography (1969a) mean length was noted for males and females as 1.61 and $1.81 \mathrm{~mm}$, respectively. The length range of Deevey's (1970; 1978b; 1982b) males is 1.7-1.9 mm and females 1.9-2.0 mm. Chen et al. (1983) and Chen and Lin (1995) gave the length of males as $1.44-1.59 \mathrm{~mm}$ and females as $1.74-1.85 \mathrm{~mm}$. The length of our specimen of male is $2.9 \mathrm{~mm}$.

\section{Acknowledgements}

The authors wish to thank Dr. M. E. Vinogradov and Dr. J. A. Rudjakov of Institute of Oceanology, Russian Academy of Sciences, for the plankton materials upon which study is based and for the environmental data presented in the station data herein. Also I am greatly indebted to A.G. Bashmanov of Institute of Marine Biology, Far East Branch, Russian Academy of Science for technical preparation of this manuscript. This work was supported by the grant from the Russian Fundamental Fund of Investigation (RFFI).

\section{References}

Alcaraz, M., Manrigues, M. and Vazgues, A. 1975. Ostracodos pelagicos del SW de Portugal: Estructura de las comunidades. 39 (2): 379-204.

Angel, M. V. 1968. The thermocline as an ecological boundary. Sarsia, 34: 299-312.

Angel, M. V. 1969a. Planktonic ostracods from the Canary Island region; their depth distributions, diurnal migrations, and community organization. Journal of Marine Biological Association, U. K., 49: 515-553.

Angel, M. V. 1969b. Repeated samples from a deep midwater planktonic ostracod community. Journal of Experimental Marine Biology and Ecology, 3: 76-89.

Angel, M. V. 1979. Studies on Atlantic halocyprid ostracods: their vertical distributions and community in the central gyre region along latitude $30^{\circ} \mathrm{N}$ from off Africa to Bermuda. Progress in Oceanography, 8: 3-124.

Angel, M. V. 1982. Halocypris inflata (Dana, 1849) and H. pelagica Claus, 1890; subling species which possibly show character displacement. In: Fossil and recent Ostracoda (Ed. R. H. Bate, F. Robinson and I. M. Sheppard). British Micropaleontological Society Chichester: 327-343.

Angel, M. V. 1993. Marine planktonic ostracods. Synopsis of the British Fauna (new Series). N 48. Published for the Linnean Society of London and the Estuarine and Coastal Sciences Association by Field Studies Council Shrewsbury: 1-240.

Angel, M. V. and Fasham, M. J. R. 1975. Analysis of the vertical and geographic distribution of the abundant species of planktonic ostracods in the North-East Atlantic. Journal of Marine Biological Association U. K., (55): 709-737.

Brady, G. S. 1880. Report on the Ostracoda dredged by H. M. S. Challenger during the years 1873-1876. In, Report of the voyage of the H. M. S. Challenger. Zoology. London, 3: 1-84.

Brady, G. S. 1897. A. supplementary report of the crustaceans of the group Myodocopa obtained during the "Challenger", Expedition, with noted on other new or imperfectly known species. Transactions of the Zoological Society of London, 14 (3): 85-100. 
Brady, G. S. and Norman, A. M. 1896. A monograph of the marine and freshwater Ostracoda of the north Atlantic and of the north-western Europe. Scientific Proceedings of the Royal Dublin Society, 5 (12): 621-784.

Chavtur, V. G. 1976. Fauna of pelagic ostracods of the Far-Eastern Seas. In: Coastal communities of the FarEastern Seas. Institut Biologii Morija AN SSSR, Vladivostok, 6: 99-109 [In Russian].

Chavtur, V. G. 1977a. Fauna of pelagic ostracods of the Halocypridae family in the northwestern part of the Pacific Ocean. Biologija Morija, 1: 28-38. [In Russian].

Chavtur, V. G. 1977b. Fauna of pelagic ostracods of the Halocypridae family in the northwestern part of the Pacific ocean. Sov. T. Mar. Biol., 3 (3): 18-26.

Chavtur, V. G. 1992. [Composition, structure and distribution bentic and pelagic ostracods of the superorder Myodocopa of temporate and cold waters of the Northern Hemisphere. [Institut Biologii Morija DVO RAN, Vladivostok: 1 - 155, 30 figs., 96 bibl. nam. Dep. VINITI, N3016 - VD2, 20. 10. 92. [In Russian].

Chen, Q., Yin, J. and Zhang, G. 1983. Studies on pelagic ostracods in the central and northern parts of the South Chine Sea. Contributions Marine Biology Research of the South Chine Sea, 3 (1): 82-132.

Chen, R. 1978. Ostracoda in the coastal water of East Chine Sea. Journal of Oceanology (Peoples Republic of Chine), 8: 39-52.

Chen, R. 1982. The distribution of planktonic Ostracoda along the western coast of Taiwan Straits. Acta Oceanologica Sinica, 1 (2): 289-298.

Chen, R. and Lin, J. 1991. Ecological characteristics of planktonic Ostracoda in the western waters of Taiwan Straits. Acta Oceanologica Sinica, 10 (2): 289-296.

Chen, R. and Lin, J. 1994a. Ecological characteristics of Ostracoda in the South Huanghai Sea and East Chine Sea. Acta Oceanologica. Sinica, 13 (3): 401-412.

Chen, R. and Lin, J. 1994b. Ecological study on Ostracoda in the central South Chine Sea. Acta Oceanologica. Sinica, 13 (3): 413-423.

Chen, R. and Lin, J. 1994c. The distribution of planktonic Ostracoda between the source of Kuroshio and west of Taiwan Strait. Acta Oceanologica Sinica, 13 (3): 445-452.

Chen, R. and Lin, J. 1995. Pelagic Ostracoda in China Seas. China Ocean 1-134. [In Chinese].

Claus, C. 1874a. Die Gattungen und Arten der Halocypriden. Verhandlungen der Zoologisch-Botanischen Gesellschaft in Wien, 24: 175-178.

Claus, C. 1874b. Die Familie der Halocypriden. Schriften zoologischen Inhalts. Wien., 1: 1-16.

Claus, C. 1890. Die Gattungen und Arten der Mediterranen und Atlantischen Halocypriden. Arbeiten aus dem Zoologischen Institut der Universität zu Wien, 9: 1-33.

Claus, C. 1891. Die Halocypriden des Atlantischen Ocean and Mittelmeer. Wien. 81 S.

Cleve, P. T. 1905. The plankton of the South African Seas. III. Halocyprididae. In Marine investigations in the South Africa. Cape Town, 4: 129-132.

Dana, J. D. 1849. Conspectus crustaceorum quae in orbis terrarium circumnavigatione Carolo Wilkes e classe reipublicae foederate duse, lexit 1849, 2: 9-61.

Dana, J. D. 1852. Crustacea: Cyproidea. United States Exploring Expedition during the years 1838-1842 under the command of Charles Wilkes. Philadelphia. 13 (2): 1277-1304.

Deevey, G. B. 1968. Pelagic ostracods of the Sargasso Sea off Bermuda. Peabody Museum of Natural History Yale University, 26: 1-125.

Deevey, G. V. 1970. Pelagic ostracods (Myodocopa, Halocyprididae) from the North Atlantic off Barbados. Proceedings of the Biological Society of Washington, 82 (62): 799-824.

Deevey, G. B. 1974. Pelagic ostracod collected on Hudson 70 between the equator and $55^{\circ} \mathrm{S}$ in the Atlantic. Proceedings of the Biological Society of Washington, 87 (32): 351-380.

Deevey, G. B. 1978a. A taxonomic and distributional study of the planktonic ostracods collected on three cruises of the "Eltanin" in the South Pacific and the Antarctic Seas, VIII Antarctic Research, 28 (3): 43-70.

Deevey, G. B. 1978b. The planktonic ostracods of the Cariaco Trench and adjacent waters. Proceedings of the Biological Society of Washington, 91 (1): 53-73.

Deevey, G. B. 1982a. A faunistic study of the planktonic ostracods (Myodocopa, Halocyprididae) collected on eleven cruises of the Eltanin between New Zealand, Australia, the Ross Sea and the South Indian Ocean. Biology of the Antarctic Sea. Antarctic Research Series, 32: 131-167.

Deevey, G. B. 1982b. Planktonic ostracods of the north Atlantic off Barbados. Bulletin of Marine Science, 32 (2): 467-488 
Deevey, G. B. 1983. Planctonic ostracods (Myodocopa, Halocyprididae) from six Eltanin cruises in South Pacific and Atlantic waters. Journal of Crustacean Biology, 3 (3): 409-412.

George, J. and Nair, V. P. 1980. Planktonic ostracods of the Northern Indian Ocean. Mahasagar-Bulletin of the National Institute of Oceanography, 13 (1): 29-44.

Gonzales, L. C. and Breman, E. 1982. Distribution of planktonic ostracoda in the surface waters of the Bonaire Basin and adjacent seas. Crustaceana, 42 (2): 201-211.

Granata, L. and Caporiacco, L. 1949. Ostracodes marins recuillis pendant les croisieres du Prince Albert 1-er de Monaco. Résultats des campagnes scientifiques accomplies sur son yacht par Albert Ier, 109: 1-51.

Hanai, T. 1959. Studies on the Ostracoda from Japan: hystorical review with bibliographic index of Japanese Ostracoda. Journal of the Faculty of Science, University of Tokyo (Section 2), 11 (4): 419-439.

Hanai, T., Ikeya, N., Ishizaki, K., Sekiguchi, Y. and Yajima, M. 1977. Checklist of Ostracoda from Japan and its adjacent seas. The University Museum, the University of Tokyo, Bulletin, 12: 1-120.

Hanai, T., Ikeya, N.and Yajima, M. 1980. Checklist of Ostracoda from Southeast Asia. The University Museum, the University of Tokyo, Bulletin, 17: 1-236.

Haury, L. R. 1976. Small-Scale Pattern of a California Current Zooplankton Assemblage. Marine Biology, 37 : 137-157.

Illes, E. J. 1953. A preliminary report on the Ostracoda of the Benguela current. Discovery Report, 26: 259-279.

Juday, C. 1906. Ostracoda of the San Diego Region. I. Halocyprididae. University of California Publications in Zoology, 3 (2): 13-38.

Leveau, M. 1967. Ostracodes pelagiques du zud-ouest de l'ocean Indien (region de Tulear). Recueil des travaux de la Station marine d'Endoume-Marseille. Fascicule hors serie. Supplement , (6): 63-70.

Leveau, M. 1969. Ostracodes pelagiques recuillis lors de la $3^{\circ}$ campagne de l'avisa "Commandant Robert Giard". Recueil des Travaux de la Station Marine d'Endoume, Marseilles, Bulletin, (8): 123-142.

Lubbock, J. 1860. On some oceanic Entomostraca collected by captain Taynbee. Transactions of the Linnean Society of London, 23 (1): 173-192.

Martens, J. M. 1981. Die pelagischen Ostracoden der Marchile I-Expedition (Südost-Pazifik), I: Verbreitung, Zoogeographie und Bedentung als Indikatoren für Wasserkörper (Crust. Ostracoda: Myodocopida). Studies Neotropical Fauna and Environment, 16: 57-97.

Martens, J. M. 1979. Die pelagischen Ostracoden der Expedition Marchile I (Südost-Pazifik), II: Systematik und Vorkommen (Crustacea: Ostracoda: Myodocopa). Mitteilungen aus dem Hamburgischen Zoologischen Museum und Institut, 76: 303-366.

Moguilevsky, A. and Angel, M. V. 1975. Halocyprid ostracods in Atlantic neuston. Marine. Biology, 32: 395-302.

Müller, G. W. 1890. Ueber Halocypriden. Zoologische Jahrbücher. Abteilung für Systematic Oekologie und Geographie der Tiere, 5: 253-278.

Müller, G. W. 1906a. Ostracoda. Wissenschaftliche Ergebnisse der deutschen Tiefsee-Expedition, 8: 1-154.

Müller, G. W. 1906b. Ostracoden der Siboga-Expedition. Siboga-Expedition. Leiden. 30: 1-40.

Müller, G. W. 1908. Die Ostracoden der Deutschen Südpolar-Expedition 1901-1903. Südpolar-Exped. 1901-1903. Zoologie. Berlin, 10 (2): 53-184.

Müller, G. W. 1912. Ostracoden. Das Tirreich. Berlin. 31: 1-434.

Poulsen, E. M. 1969a. Ostracoda - Myodocopa. Pt III A. Halocypriformes-Thaumatocypridae and Halocypridae. Dana - Rept. 75: 1-100.

Poulsen, E. M. 1969b. Ostracoda-Myodocopa from the eastern tropical Atlantic. Videnskabelige Meddelelser fra Dansk Naturhistorisk Forening, 132: 129-197.

Ramires, F. C.and Moguilevsky, A. 1971. Ostracodos planktonicos Hallados en Agues oceanicas frente a la provincia de Buenos Aires (Resultados de la XLI comissao oceanografica costa sul). Phisis. Buenos Aires, 30 (81): 637-667.

Scott, A. 1905. Report of the Ostracoda collected by Pr. Herdman, at Ceylon, in 1902. Rept. Ceylon Pearl Fish. London, 3: 365-385.

Scott, T. 1912. The Entomostraca of the Scottish National Antarctic Expedition, 1902-1904. Transactions of the Royal Society of Edinburg, 48 (3): 521-600.

Skogsberg, T. 1920. Studies on marine ostracods. Pt. 1 (Cypridinids, Halocypridinids and Polycopids). Zoologische Bijdragen, Uppsala: 1-784.

Skogsberg, T. 1931. Ostracods. Rep. Sci. Result: "Michael Sars" North Atlantic Deep-Sea Expedition 1910 (Ed. J. 
Murray, J. Hjort), 5: 1-26.

Tseng, W. Y. 1970a. The zooplankton community in the surface waters of Taiwan Strait. The Kuroshio: Proceedings of the 2nd CSK Symp. (Ed. K. Sugawara), Tokyo: 261-272.

Tseng, W. Y. 1970b. Occurrence of ostracods in the neighbouring seas of Taiwan.The Kuroshio: Proceedings of the 2nd CSK Symp. (Ed. K. Sugawara), Tokyo: 85-295.

Tseng, W. Y. 1980. The pelagic Ostracoda of Hong Kong. The marine flora and fauna of Hong Kong and Southern Chine: Proceedings of the First Int. Mar. Biol. Workshop, Hong Kong (Ed. Morton B. C. and Tsung C. K. Hong Kong: Univ. Press: 401-430.

Vavra, V. 1906. Die Ostracoden (Halocypriden und Cypridiniden) der Plankton - Expedition. Ergebnisse Plankton - Exped. Humboldt - Stiff. Kiel. Leipzig. 2: 1-76

Vinogradov, M. E. 1968. Vertical distribution of the oceanic zooplankton. Publishing House "Nauka", Moscow, 1320 [In Russian]. 